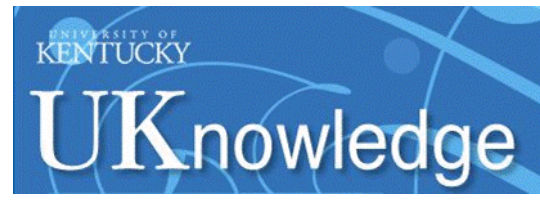

University of Kentucky

UKnowledge

Winter 2016

\title{
Planned Parenthood: Adult Adoption and the Right of Adoptees to Inherit
}

Richard C. Ausness

University of Kentucky College of Law, rausness@uky.edu

Follow this and additional works at: https://uknowledge.uky.edu/law_facpub

Part of the Estates and Trusts Commons, and the Family Law Commons

Right click to open a feedback form in a new tab to let us know how this document benefits you.

\section{Repository Citation}

Ausness, Richard C., "Planned Parenthood: Adult Adoption and the Right of Adoptees to Inherit" (2016). Law Faculty Scholarly Articles. 590.

https://uknowledge.uky.edu/law_facpub/590

This Article is brought to you for free and open access by the Law Faculty Publications at UKnowledge. It has been accepted for inclusion in Law Faculty Scholarly Articles by an authorized administrator of UKnowledge. For more information, please contact UKnowledge@lsv.uky.edu. 


\section{Planned Parenthood: Adult Adoption and the Right of Adoptees to Inherit}

\section{Notes/Citation Information}

Richard C. Ausness, Planned Parenthood: Adult Adoption and the Right of Adoptees to Inherit, 41 ACTEC L.J. 241 (2016). 


\title{
Planned Parenthood: Adult Adoption and the Right of Adoptees to Inherit
}

\author{
Richard C. Ausness*
}

\section{INTRODUCTION}

This Article is concerned with the effect of adult adoptions on the inheritance rights (in the broad sense of that term) of adult adoptees. ${ }^{1}$ The Article contends many adult adoption statutes assume the existence of a parent-child relationship in which the adopter is the "parent" and the adoptee is a "child" even though this is not true of all adult adoption cases. In addition, legislatures and courts frequently fail to differentiate between "quasi-familial" adoptions and "strategic" adoptions, particularly where inheritance rights are concerned.

Part II describes various adoption scenarios. In the case of minors, this includes the adoption of unrelated children, the adoption of descendants and collateral relatives and stepchild adoption. All of these involve a parent-child relationship that integrates the child into the adoptive family and gives rise to rights and duties on the part of both parent and child. This is not the case with adult adoptions. Even if there has been a parent-child relationship between the parties in the past, there is no present parent-child relationship, at least in the legal sense, and the adoption does not necessarily give rise to any rights or duties. Instead, adult adoptions are usually concerned with inheritance rights or other financial benefits.

Part III examines the use of adult adoption in Roman law and its eventual incorporation into the civil law systems of continental Europe. It also observes that English common law did not recognize formal adoptions until 1926, although informal adoption did occur prior to that time. Part IV surveys the development of adoption law in the United States, beginning with the adoption of minors and eventually leading to statutes authorizing the adoption of adults.

* Associate Dean for Faculty Research and Everett H. Metcalf, Jr. Professor of Law, University of Kentucky; B.A. 1966, J.D. 1968 University of Florida; LL.M. 1973 Yale Law School.

1 Technically, inheritance refers to the right of a person, under the laws of descent and distribution, to take a share of the estate of a decedent who has died without a valid will. However, in this Article, inheritance rights will also include the right to take a share of a class gift contained in an inter vivos trust or a will. 
Part V discusses the right of an adult adoptee to inherit in cases of intestacy. It concludes that in most states an adult adoptee can inherit from and through his or her adoptive parents. On the other hand, the right to inherit from the adoptee's biological family, which was once commonly recognized, is now generally not allowed.

Part VI examines the right of an adult adoptee to take as the beneficiary of a class gift in a will or trust. At one time, the "stranger to the adoption" rule resulted in the exclusion of adoptees from class gifts to those described as "children," "issue" or "heirs;" however, the modern trend is to include those who were adopted as minors in these classes unless expressly excluded. However, courts are still reluctant to admit adult adoptees to these beneficiary classes without a clear indication that the settlor or testator wants to include them.

Part VII identifies various types of adult adoption and proposes a series of rules to determine when adult adoptees should be allowed to take by intestacy or benefit from class gifts in wills or trusts created by their adoptive parents or by members of their adoptive parents' family. Part VIII discusses a few other related issues such as formalities, notice, termination and terminology relating to adult adoptions.

\section{Traditional Adoption and Adult Adoption}

The thesis of this Article is that adult adoption, at least as far as inheritance rights are concerned, is quite different from the adoption of a minor. Nevertheless, adult adoption statutes incorporate many of the principles that are more relevant to the adoption of minors. Furthermore, adult adoption statutes and court decisions interpreting them fail to distinguish between quasi-family adoptions and strategic adoptions insofar as the right to inherit is concerned.

\section{A. Adoption of Minors}

The traditional adoption process, which is primarily based on nineteenth century attitudes about the nature of the family structure, assumes that the adoptee is an orphan who will be taken in and reared by benevolent foster parents. ${ }^{2}$ In most situations, the child would not be related in any way to the adoptive parents. Based on these assumptions, the traditional adoption process is designed to sever the child's ties, if any, with his or her biological family and to fully integrate the child into the adoptive family. This is sometimes referred to as the "fresh start" theory and it is often invoked to terminate an adoptee's right to inherit

2 See In re Taylor's Estate, 285 N.W. 538, 539 (Neb. 1939). 
from his or her biological family while expanding the right to inherit from members of the adoptive family. ${ }^{3}$

Alternatively, the adoptee may be adopted by a family member such as a grandparent or collateral relative. In such cases, there will usually be an existing family relationship between the adopted child and the adoptive parent. Furthermore, the adoptive child will probably have pre-existing ties with other members of the adoptive family. For this reason, the "fresh start" theory does not seem to be particularly applicable. Therefore, adoptees in such cases usually retain the right to inherit from his or her biological parents as well as members of the adoptive family. ${ }^{4}$

Stepchild adoption is another category of traditional adoption (although it can also apply to adult adoptions). This form of adoption involves the adoption by a second spouse of a child by a prior marriage of the other spouse. In such cases, one of the parents will be the biological parent of the adopted child and the other will not. Once again, the "fresh start" concept does not accurately define the new family relationship. A provision of the Uniform Probate Code addresses the complicated question of when an adopted child can inherit from a biological parent. $^{5}$

Each of the above forms of adoption involves some sort of relationship between the adopted child and the adoptive parent. This relationship creates rights and duties on both parties similar to the rights and duties that govern the relationship between parents and their biological children. For example, during the adopted child's minority, the adoptive parents are expected to provide affection, guidance and support and the child is expected to love and obey his or her adoptive parents. These considerations, rather than inheritance rights, presumably motivate most childhood adoptions.

\section{B. Adult Adoptions}

Adult adoptions are entirely different. Familial adoptions are usually motivated by love and affection, but other adoptions are not. This distinction should be relevant to the right to of the adult adoptee to inherit from both the adoptive parent and the adoptive parent's family.

\footnotetext{
3 See Jackie Messler, Comment, The Inconsistent Inheritance Rights of Adult Adoptees and a Proposal for Uniformity, 95 Marq. L. Rev. 1043, 1046 (2012).

4 See Unif. Рrob. Code $\$ 2-119$ (c) (Unif. Law Comm'n 2010).

5 Id. § 2-119(b).
} 


\section{Adoptions Related to a Prior Parental or Family Relationship}

Adult adoption may occur where a parent-child relationship formerly existed between the adoptive parent and an unrelated adoptee. Often in such cases, a formal adoption during the child's minority may not have been possible because the adoptee's biological parents could not be found or because one of them withheld consent. ${ }^{6}$ In such cases, the adoptee must reach adulthood before the consent requirement is no longer applicable.

An adoption may also take place between related adults due to the death of the adoptee's biological parents or because the parties developed a close, but non-parental, relationship during the adoptee's minority. ${ }^{7}$ This form of adoption is sometimes employed as a means of formalizing the entry of the adoptee into the family business. ${ }^{8}$

Finally, a stepchild adoption can occur between an adult adoptee and a stepparent. The common characteristic of these various forms of adoption is the existence of a parental or family relationship between the parties and while inheritance rights may be involved, they are not the sole motivating factor for the adoption.

\section{Adoptions Related to an Existing Sexual Relationship}

The second type of adult adoption is based on the existence of a sexual, rather than a parental or family, relationship between the parties. ${ }^{9}$ One version involves the adoption of one spouse by another. This is not legal in some states, but other states do allow it. ${ }^{10}$ Adoptions of this sort are rare and are almost always motivated by a desire to create inheritance rights in the adopted spouse. A more common type of adult adoption involves same-sex partners who want to formalize their relationship in some manner. ${ }^{11}$ Of course, this does not resemble a conventional adoption since no parent-child relationship is contemplated. Rather, it represents an attempt by a same-sex couple to establish a form of marriage substitute and possibly create inheritance rights as well. The Supreme Court's recent decision in Obergefell v. Hodges ${ }^{12}$

6 See Sarah Ratliff, Note, Adult Adoption: Intestate Succession and Class Gifts Under the Uniform Probate Code, 105 Nw. U. L. Rev. 1777, 1780 n.19 (2011).

7 See Messler, supra note 3, at 1051-52.

8 See, e.g., Otto v. Gore, 45 A.3d 120, 128-29 (Del. 2012).

9 See Ratliff, supra note 6, at 1805.

10 See In re Tr. Created by Belgard, 829 P.2d 457, 460 (Colo. App. 1991); Minary v. Citizens Fid. Bank \& Tr. Co., 419 S.W.2d 340, 341 (Ky. 1967); Pennington v. Citizens Fid. Bank \& Tr. Co., 390 S.W.2d 671, 671-72 (Ky. 1965).

11 See In re Adoption of Swanson, 623 A.2d 1095, 1096 (Del. 1993); In re Adoption of Patricia S., 976 A.2d 966, 967-68 (Me. 2009); In re Adoption of Spado, 912 A.2d 578, 579-80 (Me. 2007); Ex parte Libertini, 224 A.2d 443, 444-45 (Md. 1966).

12135 S. Ct. 2584, 2604-05 (2015). 
has greatly reduced the need for this form of adoption. Finally, heterosexual partners who do not wish to marry may also chose adoption as a kind of marriage substitute. ${ }^{13}$

\section{Adoptions by Unrelated Persons for Purposes Other Than Inheritance}

This type of adoption is motivated by non-sexual love and affection. It usually involves long-time friends or a caregiver and a dependent person. ${ }^{14}$ Although inheritance rights may be involved, they are not the principal reason for the adoption. In addition, people sometimes use adoption to achieve other economic or strategic goals. For example, adoption may affect a party's right to contest a will, ${ }^{15}$ to take advantage of an anti-lapse ${ }^{16}$ or a pretermitted child ${ }^{17}$ statute, to make a workers' compensation claim, ${ }^{18}$ to seek Social Security benefits, ${ }^{19}$ to benefit from rent control regulations ${ }^{20}$ or to take as the beneficiary of a life insurance policy. ${ }^{21}$ In addition, adoption may affect inheritance tax rates ${ }^{22}$ and it may also affect the amount that a surviving spouse can receive under dower ${ }^{23}$ or elective share ${ }^{24}$ statutes.

\section{Adoptions by Unrelated Persons Principally Intended to Create Inheritance Rights for One or Both Parties}

This form of adult adoption may be viewed as a will substitute. Unfortunately, it has resulted in much litigation when the adoptee seeks to inherit from a member of the adoptive parent's family or when the

13 See Greene v. Fitzpatrick, 295 S.W. 896, 897-98 (Ky. 1927).

14 See In re Adoption of Elizabeth P.S. by Eileen C., 509 N.Y.S.2d 746, 748 (Fam. Ct. 1986).

15 See In re Williams' Estate, 36 P. 407, 410 (Cal. 1894); Collamore v. Learned, 50 N.E. 518, 519 (Mass. 1898); In re Heye's Estate, 269 N.Y.S. 530, 540 (Sur. Ct. Monroe Cty. 1933); Taylor v. Taylor, 40 S.W.2d 393, 393-96 (Tenn. 1931).

16 See In re Estate of Goulart, 35 Cal. Rptr. 465, $472-74$ (Dist. Ct. App. 1963); In re Moore's Estate, 47 P.2d 533, 534 (Cal. Dist. Ct. App. 1935); Warren v. Prescott, 24 A. 948, 949 (Me. 1892); Hoellinger v. Molzhon, 41 N.W.2d 217, 219 (N.D. 1950).

17 See Dreyer v. Schrick, 185 P. 30, 31 (Kan. 1919); In re Estate of Flowers, 848 P.2d 1146, 1147 (Okla. 1993); In re Roderick's Estate, 291 P. 325, 325-26 (Wash. 1930); In re Hebb's Estate, 235 P. 974, 975 (Wash. 1925).

18 See Fairchild Constr. Co. v. Owens, 224 So. 2d 571, 572 (Miss. 1969).

19 See Coker v. Celebrezze, 241 F. Supp. 783, 783-84, 787 (E.D. Tenn. 1965).

20 See 333 E. 53d St. Assocs. v. Mann, 503 N.Y.S.2d 752, 754 (App. Div. 1986).

21 See Melville v. Wickham, 169 S.W. 1123, 1125 (Tex. Civ. App. 1914).

22 See In re Cook's Estate, 79 N.E. 991, 993-94 (N.Y. 1907); In re Hagar's Estate, 126 A. 507, 507-08 (Vt. 1924).

23 See Buckley v. Frazier, 27 N.E. 768, 769 (Mass. 1891).

24 See Atchison v. Atchison's Ex'rs, 12 S.W. 942, 943-44 (Ку. 1890). 
adoptee seeks to benefit from a class gift in a will or trust created by a member of the adoptive parent's family.

\section{HistoricAl BACKGround}

\section{A. The Roman Law of Adoption}

Adoption, including adult adoption, was commonly practiced in many ancient cultures. ${ }^{25}$ As far back as 1750 B.C., adoption is mentioned in the Code of the Babylonian King, Hammurabi. ${ }^{26}$ It appears from the Bible that some sort of adoption was also practiced by the Jewish tribes of ancient Israel. ${ }^{27}$ In ancient Athens, a citizen could adopt another person either during his lifetime or by will. ${ }^{28}$ Adoption was common in ancient Rome and usually involved the adoption of adult males. ${ }^{29}$ Wealthy Romans relied on adoption to perpetuate the family name in cases where a married couple had failed to produce a male heir. ${ }^{30}$ Adoption was also used to provide for the continued performance of religious rites to honor family gods and ancestors, a matter of great importance to the ancient Romans. ${ }^{31}$

25 See Stephen B. Presser, The Historical Background of the American Law of Adoption, 11 J. FAM. L. 443, 445-46 (1972).

26 See Louis Quarles, The Law of Adoption-A Legal Anomaly, 32 MArq. L. Rev. 237, 240 (1949).

27 Id. at 239. According to the Bible, after the death of Esther's parents, Mordecai, a relative of her father, adopted Esther and raised her as his own daughter. See David M. Smolin, Of Orphans and Adoption, Parents and the Poor, Exploitation and Rescue: A Scriptural and Theological Critique of the Evangelical Christian Adoption and Orphan Care Movement, 8 Regent J. InT'L L. 267, 279-80 (2012).

28 Quarles, supra note 26, at 239.

29 See Ruth-Arlene W. Howe, Adoption Practice, Issues, and Laws 1958-1983, 17 FAM. L.Q. 173, 174 (1983). One reason that women were seldom adopted was because they could not perpetuate the family name of the adopter. See Paulo Barrozo, Finding Home in the World: A Deontological Theory of the Right to be Adopted, 55 N.Y.L. ScH. L. Rev. 701, 706 (2011).

30 See John Francis Brosnan, The Law of Adoption, 22 Colum. L. Rev. 332, 332 (1922); Leo Albert Huard, The Law of Adoption: Ancient and Modern, 9 VAND. L. Rev. 743, 745 (1956).

31 See Barbara Bennett Woodhouse, Waiting for Loving: The Child's Fundamental Right to Adoption, 34 CAp. U. L Rev. 297, 311 (2005); Jan Ellen Rein, Relatives by Blood, Adoption, and Association: Who Should Get What and Why (The Impact of Adoptions, Adult Adoptions, and Equitable Adoptions of Intestate Succession and Class Gifts), 37 VAND. L. REV. 711, 714 (1984). The performance of sacra privata, religious observances or rituals in honor of the family's ancestors, was a significant obligation for the head of the family. Therefore, if the paterfamilias was elderly and likely to die without heirs, it was necessary for him to acquire a substitute son by adoption who could perform these rites. See W. W. Buckland \& Arnold D. McNair, Roman Law \& Common Law: A Comparison in Outline 42 (2d ed. 1952); Laura J. Schwartz, Models for Parenthood in Adoption Law: The French Conception, 28 Vand. J. Transnat'L L. 1069, 1092 (1995). 
Adoption could also be used to further political objectives. One of the strangest examples of this practice involved Publius Claudius Pulcher. Claudius wished to become a tribune, but as a member of the patrician class was barred from holding that office because it was reserved for plebians. ${ }^{32}$ The 34-year-old Claudius solved this problem by having a 20-year-old plebian named Fonteius adopt him. ${ }^{33}$ Julius Caesar, in his capacity as pontifex maximus, presided over this dubious adoption ceremony. ${ }^{34}$ As a newly adopted member of a plebian family, Claudius, now known as Clodius, was duly elected tribune. ${ }^{35}$

Finally, Roman emperors often chose their successors by adopting them. ${ }^{36}$ For example, in his will, Julius Caesar adopted his greatnephew, Octavian (subsequently known as Augustus), to legitimize his succession as ruler. ${ }^{37}$ Octavian himself adopted his son-in-law, Tiberius, thereby assuring his succession as emperor. ${ }^{38}$ Later emperors continued the practice of adopting their successors as a means of easing their way to the imperial throne. Thus, Caligula was adopted by Tiberius; ${ }^{39}$ Nero was adopted by Claudius; ${ }^{40}$ Trajan was adopted by Nerva; ${ }^{41}$ Antonius Pius was adopted by Hadrian; ${ }^{42}$ and Marcus Aurelius was adopted by Antonius Pius. ${ }^{43}$

32 Claudius intended to use his power as tribune to prosecute Cicero for executing members of the Catiline Conspiracy when Cicero served as Consul. See Christian Meier, Caesar: A Biography 213-14 (David McLintock trans., 1982).

33 Id. at 213-15. See also Arthur D. Kahn, The Education of Julius Caesar: A Biography, A Reconstruction 203 (1986).

34 See KaHN, supra note 33, at 203.

35 See Alan Watson, The Law of The Ancient Romans 39 (1970). Unfortunately for Claudius/Clodius, his political career came to an abrupt end when he was murdered in 52 B.C. by henchmen of his political rival, Milo. Politics could be deadly in those days. See also Michael Grant, History of Rome 225 (1978).

36 See Smolin, supra note 27, at 290. Of course, Julius Caesar never became an emperor, although he was made dictator for life. See also KAHN, supra note 33, at 203. However, Octavian assumed the title of princeps along with the honorific Augustus given to him by the Roman Senate.

37 See 1 T. Rice Holmes, The Architect of the Roman Empire 10 (AMS Press, Inc. 1977) (1928); see KAHN, supra note 33, at 203; E.S. Shuckburgh, Augustus Caesar 16 (1995).

38 See E.S. Shuckburgh, Augustus Caesar 255 (1995); see also Michael Grant, The Twelve Caesars 85 (1975). Curiously, Augustus also adopted his wife, Livia, in his will, bestowing on her the name Julia Augusta.

39 See Smolin, supra note 27, at 292.

40 See Michael Grant, Nero 25 (Dorset Press 1989) (1970); see also Miriam T. Griffin, Nero: The End of a Dynasty 96 (1984).

41 See Grant, supra note 35, at 293-94.

42 See Stewart Perowne, Hadrian 178 (Greenwood Press 1976) (1960).

43 See Grant, supra note 35, at 353. 
Roman law recognized two forms of adoption, adrogation and adoption. ${ }^{44}$ In either case, the adoptee would take the name of his new father, while keeping his old family name as a surname. ${ }^{45}$ Furthermore, the adoptee would become subject to the potestas of the adopter. ${ }^{46}$ The more ancient of the two procedures, adrogatio or adrogation, was reserved for persons who were sui juris, that is, not subject to power of a paterfamilias. ${ }^{47}$ During the republican period, adrogation involved two stages. First, the college of pontiffs conducted a preliminary investigation to determine if the adopter could no longer have children. ${ }^{48}$ If the pontiffs approved, the petition was submitted to an assembly of the people known as the comitia curiata. ${ }^{49}$ Both the adopter and the adoptee had to appear before the comitia and agree to the adoption. Thereupon, the comitia curiata on behalf of the Roman people would give its approval to the adoption. ${ }^{50}$

The second form of adoption or adoptio was employed by those who were alieni juris, that is, subject to the partia potestas or parental power of the father even though they were adults. ${ }^{51}$ This involved the biological father "selling" his son three times to a third party by a procedure known as mancipatio. ${ }^{52}$ Each time the sale took place, the buyer would manumit the adoptee, thereby reestablishing the biological fa-

44 See Walter J. Wadlington, III, Minimum Age Difference as a Requisite for Adoption, 1966 Duke L.J. 392, 395 (1966).

45 See Brosnan, supra note 30 , at 333.

46 See Barrozo, supra note 29, at 706; see also Presser, supra note 25, at 447 . See Watson, supra note 35 , at 37-39, for a discussion of the patria potestas, or power of the father.

47 See Quarles, supra note 26, at 240.

48 See Watson, supra note 35 , at 39 . The adopter had to be at least sixty years old and must have tried to procreate when he was younger and presumably able to have children. Furthermore, because adoption meant that the adoptee was merged into the family of the adopter, some provision would have to be made to ensure that the domestic cult of the adoptee's family was continued. See also H.F. Jolowicz, Historical Introduction to the Study of Roman Law 119-20 (1932).

49 See Huard, supra note 30, at 745. Roman citizens divided themselves into thirty groups called curiae. The curiae were further divided into three groups of ten. Each group or tribus provided a squadron of cavalry. During the late Republican period, the comitia curiata primarily exercised various religious functions, including rituals associated with adrogation. See Wolfgang Kunkel, An Introduction to Roman Legal and Constitutional History 9-10 (J.M. Kelly trans., 6th ed. 1973). Originally, only Roman citizens could adopt by adrogation because they alone were members of the comitia. See Buckland \& McNair, supra note 31, at 42 . Women were also barred from using this procedure to adopt or be adopted for the same reason. See Quarles, supra note 26 at 240.

50 See Watson, supra note 35 , at 39 . The term "adrogatio" takes its name from the rogatio or bill that was submitted to the comitia. See Jolowicz, supra note 48, at 119.

51 See Jolowicz, supra note 48, at 119.

52 See Watson, supra note 35 , at 38. 
ther's potestas. ${ }^{53}$ After the third sale, however, the father's patria potestas would be lost. ${ }^{54}$ The adoptive parent would then bring an action against the third party who now held the adoptee in mancipio, claiming that the adoptee was his son. ${ }^{55}$ Since the entire process was collusive in nature, the third party would not contest the adoptive father's claim and the praetor would declare that the adoptee was now the son of the adoptive parent. ${ }^{56}$ This judgment would effectively invest the adoptive parent with patria potestas over the adoptee..$^{57}$

It can be seen that adoption in ancient Rome was not particularly concerned with the nurturing of small children as are most adoptions in this country. Instead, adoption usually involved adult males and was chiefly concerned with the perpetuation of religious rites or the preservation of the adopter's family. ${ }^{58}$ Nor was this view of adoption confined to Rome; it eventually spread to much of continental Europe as well.

\section{B. Continental Europe}

After the fall of the Roman Empire, formal adoptions became less common, although they did not disappear completely. ${ }^{59}$ During the medieval and early modern periods, adoption was primarily used as a means of ensuring the succession of the adopter's property when he had no children. ${ }^{60}$ In such cases, adoptees were generally related to the adopter. In addition, adopters who had no legitimate children sometimes tried to legitimize their illegitimate children by means of adoption in order to pass their property on to them. ${ }^{61}$ Adoption was also sometimes employed to cut off the rights of collateral relatives by adopting a grandchild or other remote relative and thereby reducing the degree of kinship between them. ${ }^{62}$ However, in most parts of continental Europe feudal customary law required the successor of a feudal tenant to be a lineal descendant, a requirement that could not be satisfied by adop-

53 See id. at 38-39.

54 See Jolowicz, supra note 48, at 119.

55 See id.

56 See id.

57 See Quarles, supra note 26, at 240; see also In re Appeal of Woodward, 70 A. 453, 455-56 (Conn. 1908). Later, in the reign of Justinian, this procedure was replaced by one where the three parties simply appeared before a magistrate. See Brosnan, supra note 30, at 332; see Howe, supra note 29, at 174.

58 See Presser, supra note 25, at 452.

59 See Joseph W. McKnight, The Shifting Focus of Adoption, in Critical Studies in Ancient Law, Comparative and Legal History 297, 299 (John W. Cairns \& Olivia F. Robinson eds., 2001).

$60 I d$. at $299,303$.

$61 \mathrm{Id}$. at 302.

$62 \mathrm{Id}$. at 303. 
tion. ${ }^{63}$ In all likelihood, this explains why adoption does not appear to have been widely practiced during this period. ${ }^{64}$

Nevertheless, the influence of Roman law, including the institution of adult adoption, gradually gained acceptance in much of continental Europe, especially in Italy, France and Spain. For example, a study of litigation in northern Italy during the sixteenth and seventeen centuries by Professor Joseph McKnight revealed a large number of adult adoption cases. ${ }^{65}$ Formal adoptions were rare in France prior to the French Revolution. ${ }^{66}$ However, in 1804 the Napoleonic Code or Code Civil established a formal adoption procedure. ${ }^{67}$ The Code clearly authorized the adoption of adults since it provided that no adoption could take place until the adoptee had reached the age of majority. ${ }^{68}$ French legislation now distinguishes between the adoption of children (adoption plénière) and adult adoption (adoption simple). ${ }^{69}$

In Germany prior to its unification in 1871, the various German states maintained their own legal systems, and a number of them, such as Prussia, Bavaria, Saxony and Baden, enacted laws authorizing childhood adoption in the eighteenth and nineteenth centuries. ${ }^{70}$ In 1900 , the new the German Civil Code established a formal procedure for adoption, which apparently authorized adult adoptions. ${ }^{71}$ Spain also ap-

$63 I d$. at 302 .

$64 \mathrm{Id}$. at 303 .

$65 \mathrm{Id}$. at 301.

66 See Sheryl L. Sultan, Note, The Right of Homosexuals to Adopt: Changing Legal Interpretations of "Parent" and "Family", 10 J. SuFfolk ACAD. L. 45, 50-51 (1995). However, research by Kristin Elizabeth Gager into local public records in France indicates that childless couples often adopted abandoned or destitute children during this period. See Kristin Elizabeth Gager, Blood Ties and Fictive Ties: Adoption and Family Life in Early Modern France 8 (1996).

67 See Schwartz, supra note 31, at 1093.

68 See Sultan, supra note 66, at 51. However, the Code did prepare the way for the eventual adoption of minors by creating something called an officious tutorship. See Brosnan, supra note 30 , at 334.

69 See Rachel G. Fuchs, Contested Paternity: Constructing Families in Modern France, 235-36 (2008).

70 See Harry D. Krause, Creation of Relationships of Kinship, in IV InTERnATIONAL EnCyClopedia OF Comparative Law 74 (Aleck Chloros et al. ed., 1976).

71 See Brosnan, supra note 30, at 334. Apparently, as the experience of Nazi foreign minister Joachim von Ribbentrop illustrates, adult adoption could be used to acquire noble status. In 1925, Gertrud von Ribbentrop, a Prussian aristocrat, adopted her 32year-old relative, thereby enabling him to add the coveted prefix "von" to his name. In return, Joachim provided her with a generous pension. See JoHN Weitz, HitLER's Diplomat: The Life and Times of Joachim von Ribbentrop 8 (1992). More recently, Zsa Zsa Gabor's husband, Prince Frederic von Anhalt, obtained his title of "prince" by adoption. Another example of social climbing through adoption involves Ilonka Kerekes, an Austrian citizen, who changed her name to Ilonka Fürstin von Sayn-Wittgenstein after being adopted as an adult by a German prince. See Hadas Alexandra Jacobi, Note, 
parently recognized adoption, including adult adoption, and imported the practice to its American colonies. ${ }^{72}$

\section{England}

It is often claimed that the common law of England did not recognize the concept of adoption. ${ }^{73}$ In that country, inheritance was restricted to heirs of the blood. ${ }^{74}$ Although strangers were sometimes taken in to English families and treated as natural children, there was no legal procedure available for the parties to formalize their relationship and these children had no right to inherit their adoptive parents' property. ${ }^{75}$ It was not until 1926, when Parliament passed the Adoption of Children Act, ${ }^{76}$ that adoption was officially authorized. ${ }^{77}$ England's most recent adoption law, the Adoption and Children Act of 2002, declares that only children below that age of eighteen can be adopted. ${ }^{78}$

\section{Adult Adoption in the United States}

Legal adoption did not take root in the United States until the midnineteenth century. ${ }^{79}$ Furthermore, the earliest adoption statutes were concerned with the adoption of minor children and either failed to mention the possibility of adult adoption or expressly excluded it. ${ }^{80}$ In most cases, statutes expressly allowing the adoption of adults did not appear until the twentieth century. ${ }^{81}$

\section{A. Adoption of Minor Children}

Although no state enacted a general adoption statute until the middle of the nineteenth century, quasi-adoptions of children took place in

A Fürstin By Any Other Name? European Citizenship and the Limits of Individual Rights in the E.C.J., 17 Colum. J. Eur. L. 643, 646 (2011).

72 See Huard, supra note 30, at 747-48.

73 See Brosnan, supra note 30, at 335.

74 See Huard, supra note 30, at 745-46.

75 Id. at 746.

76 Id. See also Adoption of Children Act 1926, 16 \& 17 Geo. 5 c. 29 (Eng.)

77 However, the Elizabethan Poor Laws provided that orphans and impoverished children could be indentured as apprentices where they would become members of their master's household and be taught a useful trade. See Presser, supra note 25, at 453-55; Janet Hopkins Dickson, Comment, The Emerging Rights of Adoptive Parents: Substance or Specter?, 38 UCLA L. REv. 917, 923 (1991).

78 In 1962, Somerset Maugham adopted his secretary, Alan Searle. However, the adoption took place in France. See Ted Morgan, Maugham: A Biography 607 (1980).

79 See Brosnan, supra note 30 , at 335 .

80 See Dickson, supra note 77, at 924; Brosnan, supra note 30, at 335-36.

81 Adult Adoption, 1972 WAsH. U. L. Q. 253, 255 (1972). 
America prior to that time just as they did in England. ${ }^{82}$ In some cases, relatives took in orphans and raised them as their own. ${ }^{83}$ In the South, wealthy couples sometimes allowed orphans who were not relatives to live with them as family members. ${ }^{84}$ Finally, during the eighteenth and nineteenth centuries, children were often "put out" to family members to be educated or trained as apprentices. ${ }^{85}$

Prior to 1851 , legal adoptions were uncommon. ${ }^{86}$ However, it was possible in some states to obtain legislative approval of an adoption by means of special legislation. ${ }^{87}$ In addition, Texas and Louisiana recognized formal adoptions that had been obtained pursuant to Spanish or French law when those states were subject foreign control. ${ }^{88}$ However, the first general adoption law was enacted by the state of Massachusetts in 1851.89 The statute provided that the adopted child would be treated as though he or she had been born to the adoptive parents in lawful wedlock and required a finding that the adopting parents had the capacity to bring up the child and provide the child with adequate nurture and education. ${ }^{90}$ A large number of states followed suit and by 1931 all of them had enacted general adoption statutes for children. ${ }^{91}$

\section{B. Adoption of Adults}

Adult adoption was relatively rare in the nineteenth century. However, by the middle of the twentieth century, most states allowed it, either by a specific statute or by judicial interpretation their general adoption statutes.

82 See Woodhouse, supra note 31 , at 315.

83 See Presser, supra note 25, at 457-58.

84 See id.

85 See Dickson, supra note 77, at 923.

86 But see Yasuhide Kawashima, Adoption in Early America, 20 J. FAM. L. 677, 695 (1982) (arguing that "[t]he practice of adoption in the colonial period was more prevalent than has thus far been realized."). According to Professor Kawashima, an early example of adult adoption in America occurred in 1643 when a certain Robert Lawson, in his will, adopted his friend, Robert West, and made him his heir. Id. at 689.

87 See Naomi Cahn, Perfect Substitutes or the Real Thing?, 52 Duke L.J. 1077, 110506 (2003).

88 See Huard, supra note 30, at 747.

89 See Brosnan, supra note 30, at 335. Mississippi enacted a general adoption law in 1846 , but it was not as comprehensive as that of Massachusetts. See Huard, supra note 30 , at 748 .

90 Cahn, supra note 87, at 1112-14.

91 See Mindy Schulman Roman, Note, Rethinking Revocation: Adoption from a New Perspective, 23 Hofstra L. REv. 733, 737 (1995). 


\section{Judicial Recognition of Adult Adoption}

At one time, some courts refused to allow adults to be adopted in the absence of language in the state's adoption statute specifically allowing it. ${ }^{92}$ Appeal of Ritchie ${ }^{93}$ involved an appeal from a lower court's refusal to allow a 65-year-old widower to adopt a 26-year-old male, Robert Hun Hee Pai, in order to make him his son and heir. ${ }^{94}$ On appeal, the Nebraska Supreme Court observed that the state's statutory adoption procedure only applied to the adoption of a "minor child." 95 The petitioners contended that the trial court, in the exercise of its equitable powers, could have authorized Pai's adoption notwithstanding the statutory language restricting adoption to minor children. ${ }^{96}$ However, the court reiterated the conventional view that adoption was purely statutory in nature and that courts were not free to expand the scope the state's adoption statutes. ${ }^{97}$ Accordingly, it affirmed the lower court's decision. ${ }^{98}$

More recently, the Alabama Supreme Court applied similar reasoning in Doby v. Carroll. ${ }^{99}$ In that case, Kenneth Doby, then 23 years old, was adopted by Clara McCallister, an adult who died soon thereafter. ${ }^{100}$ After her death, the guardian of McCallister's estate sought to annul the probate court's adoption order on the grounds that Alabama did not authorize the adoption of an adult. ${ }^{101}$ After a hearing on the matter, the probate court set aside the adoption and Doby appealed. ${ }^{102}$ The appellate court began by observing that the right to adopt was purely statutory and "unless the statute by express provision or necessary implication confers the right of adoption, such right does not exist."103 The court acknowledged that the Alabama court in Sheffield v. Frank$\operatorname{lin}^{104}$ had ruled that the use of the word "child" in the 1886 Code re-

92 See, e.g., Doby v. Carroll, 147 So. 2d 803, 805 (Ala. 1962); First Nat'l Bank of St. Petersburg v. Mott, 133 So. 78, 79 (Fla. 1931); Bartholow v. Davies, 114 N.E. 1017, 101920 (Ill. 1916); In re Appeal of Ritchie, 53 N.W.2d 753, 755 (Neb. 1952); In re Moore, 14 R.I. 38, 38 (1882).

93 In re Ritchie, 53 N.W.2d at 753.

$94 \mathrm{Id}$. at 754 . Ritchie offered evidence of a contract in which Ritchie agreed to adopt Pai and devise certain property to him if Pai changed his surname to "Ritchie." Id. at 755 .

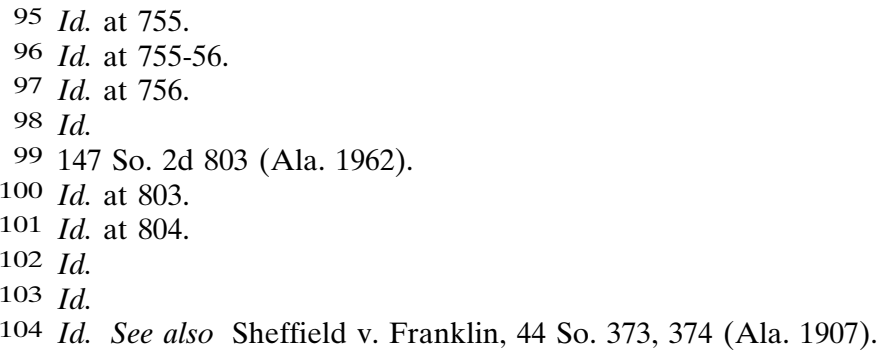


ferred to the status of the adoptee and did not require that the adoptee be a minor. However, the court determined that the statute involved in the Sheffield case had been superseded in 1931 by a new adoption statute which referred the adoption of a "minor child." 105 Therefore, the court concluded that the 1931 statute, which was in effect at the time of Doby's adoption, did not authorize the probate court to permit the adoption of an adult. 106

However, other courts have interpreted general adoption statutes to allow the adoption of adults as well as minors. ${ }^{107}$ One of the earliest decisions to uphold an adult adoption was Collamore v. Learned, ${ }^{108} \mathrm{de}-$ cided by the Massachusetts Supreme Judicial Court in 1898. In Collamore, certain relatives of John Collamore challenged the adoption of three adult nieces and nephews. ${ }^{109}$ The petitioners contended that the adoption was an invalid will substitute whose sole purpose was to prevent them from contesting Collamore's will. ${ }^{110}$ In response, the court declared that Collamore could dispose of his property as he saw fit and was free to adopt his nieces and nephews and make them his heirs. ${ }^{111}$

Scott v. Peters ${ }^{112}$ involved the adoption of a 32-year-old married woman by John W. Penn. After Penn died intestate in 1924, a niece and grandniece challenged the validity of the adoption. ${ }^{113}$ In response to the heirs' argument that the statute did not allow for the adoption of an adult, the court pointed to a provision that required parental consent for the adoption of a minor child. ${ }^{114}$ According to the court, this implied that the statute distinguished between the adoption of a minor, where parental consent was required, and the adoption of an adult, where it was not. ${ }^{115}$

State ex rel. Buerk v. Calhoun ${ }^{116}$ also involved the adoption of a married woman. The trial judge dismissed the relator's petition to adopt a 31-year-old married woman even though she and her husband con-

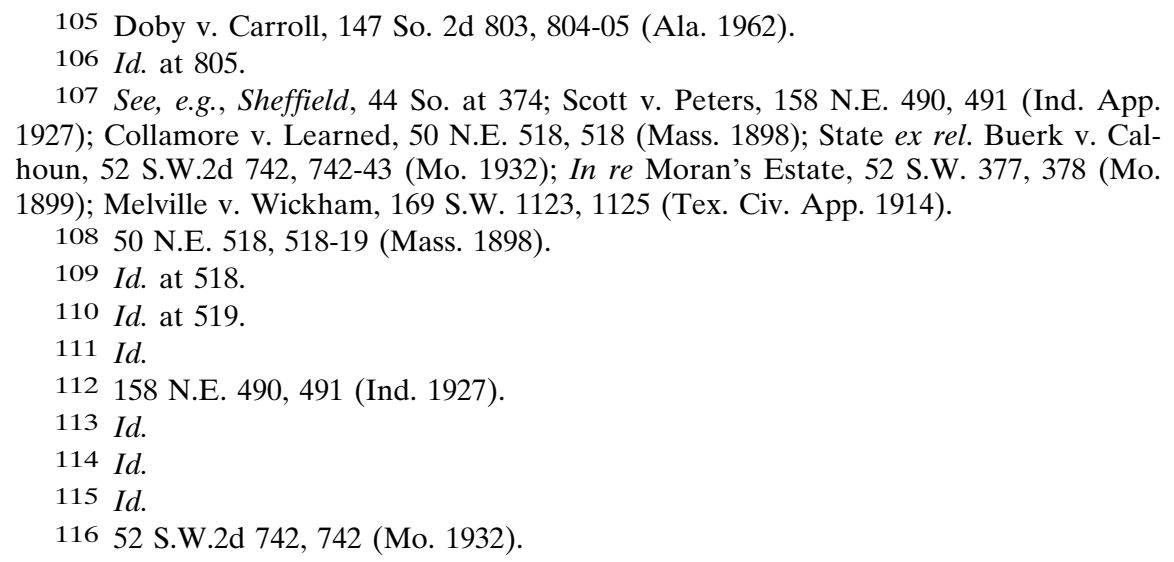


sented to the adoption. ${ }^{117}$ The trial judge found that the court did not have the power to authorize the adoption of an adult and the relator brought a mandamus action to compel the judge to grant the adoption. ${ }^{118}$ On appeal, the Missouri Supreme Court acknowledged that the adoption statute referred to the person seeking to be adopted as a "child" rather than a "person." 119 However, the court concluded that the word "child" was used "in the sense of its relation to the word "parent' and does not signify minority." 120 Furthermore, the court pointed out that another provision of the adoption statute declared that parental consent was needed to adopt a person under the age of 21 , thereby suggesting that persons over the age of 21 could be adopted without parental consent. ${ }^{121}$ Consequently, the court ordered the lower court to hold a hearing on the adoption petition. ${ }^{122}$

\section{Adult Adoption Statutes}

Most states have now enacted statutes that expressly allow adults to be adopted. ${ }^{123}$ Adult adoption procedures are normally much simpler than those that apply to the adoption of minors. ${ }^{124}$ For example, in adult adoption cases, many statutes do not require an extensive inquiry into whether a proposed adoption is in the "best interests" of the adoptee. ${ }^{125}$ Nor is parental consent typically required as it is in the case of the adoption of a minor. ${ }^{126}$

\section{a. Requirements, Restrictions and Prohibitions}

Some states restrict adult adoption or impose requirements or prohibitions on the practice. For example, a few states require the presence of a pre-existing parent-child relationship between the adopting parties. Others mandate that the spouse or parents of the adoptee con-

\footnotetext{
117 Id.

$118 I d$.

$119 I d$.

$120 \mathrm{Id}$.

121 Id. at 743.

122 Id.

123 See Brynne E. McCabe, Note, Adult Adoption: The Varying Motives, Potential Consequences, and Ethical Considerations, 22 Quinnipiac Prob. L.J. 300, 302 (2009). See also Unif. Adoption Act § 5-101(a), 9 U.L.A. 109-10 (1994).

124 See Chelsi Honeycutt, Comment, Careful Cutting Too Many Ties: Issues with Establishing a Parent-Child Relationship via Adoption in Texas and a Potential Solution, 5 Est. Plan. \& Community Prop. L.J. 171, 174 (2012).

125 See, e.g., In re Adoption of Swanson, 623 A.2d 1095, 1098-99 (Del. 1993).

126 Angela Chaput Foy, Adult Adoption and the Elder Population, 8 MArq. Elder's Advisor 109, 117 (2006).
} 
sent to the adoption. A few states also prohibit gay couples or heterosexual lovers from adopting one another.

i. Pre-existing parent-child relationship

A number of adult adoption statutes follow the Roman principle "adoptio naturam imitatur" (adoption imitates nature) ${ }^{127}$ and require the adopting parent to be a certain number of years older that the adopted child. ${ }^{128}$ This issue arose several years ago in New Jersey where a court refused to allow an adult adoption. In re Adoption of L.C. ${ }^{129}$ involved an attempt by a childless married couple, aged 50 and 53, to adopt an unmarried 52-year-old disabled woman. ${ }^{130}$ New Jersey's adult adoption statute declared that an adoption would not be granted unless "there is an age difference of at least 10 years between adopting parents and the adoptee ...."131 According to the court, the legislature imposed this requirement because it wanted to ensure some semblance of a traditional parent-child relationship between the parties to the adoption. ${ }^{132}$ At the same time, the statute permitted a court to waive this requirement if it found that the best interests of the adoptee would be promoted by the adoption. ${ }^{133}$

Since the parties failed to satisfy the statute's age difference requirement, the court considered the best interest question. Conceding that there was no case law on this issue in New Jersey, the court turned to New York and Delaware for guidance. ${ }^{134}$ Although the adult adoption statutes in these states did not have an age difference requirement, they did require that a parent-child relationship exist between the parties prior to the adoption and concluded that the New Jersey adoption statute also required the existence of a parent-child relationship when the age difference requirement was not met. ${ }^{135}$ In this case, the parties never characterized their relationship as that of parents and child, but rather insisted that they operated as a "team of equals." 136 Furthermore, the parties did not seek adoption for the purpose of creating in-

127 See Wadlington, supra note 44 , at 394.

128 See Conn. Gen. Stat. § 45a-734(a) (2016); Mass. Gen. Laws ch. 210, § 1 (2016); Nev. Rev. Stat. § 127.190(1) (2015); N.J. Stat. Ann. § 2A:22-2 (2015); Va. Code Ann. $\S 63.2-1243$ (2016); see also McCabe, supra note 123, at 302-03.

129920 A.2d 155, 156 (N.J. Super. Ct. Law Div. 2006).

$130 \mathrm{Id}$.

131 Id. at 157 (discussing N.J. StAt. AnN. § 2A:22-2).

132 See id. at 158.

133 N.J. Stat. Ann. § 2A: 22-2.

134 See In re Adoption of L.C., 920 A.2d 155, 159 (N.J. Super. Ct. Law Div. 2006).

135 Id. at $159-61$.

136 Id. at 161 . 
heritance rights or providing for perpetual care. ${ }^{137}$ In sum, the court found no evidence that the purpose of the adoption was to promote the interests of the adoptee. ${ }^{138}$ Therefore, it denied the adoption petition. ${ }^{139}$

Some states expressly condition adult adoption on the pre-existence of a prior parent-child relationship between the adopting parties or require that the adoptive child reside in the adoptive parent's household for a certain period of time. ${ }^{140}$ The first requirement is illustrated by $I n$ re Adoption of Huitzil. ${ }^{141}$ In that case, Donald and Patricia Kaufman, a married couple, petitioned to adopt an eighteen-year-old orphan. ${ }^{142}$ Prior to reaching his majority, Mr. Hiutzel lived with his older brother, a college student at Miami University. ${ }^{143}$ However, he also ate meals with the Kaufmans and developed a close friendship with them and their children. ${ }^{144}$ Nevertheless, the lower court dismissed the petition, finding that Huitzil's relationship with the Kaufmans did not constitute a childfoster parent relationship as required by the statute. ${ }^{145}$

The appeals court found that while the petitioners provided Huitzil with a great deal of guidance and emotional support, they did not make any substantial contribution to his support, education or medical care. ${ }^{146}$ Furthermore, Huitzil did not reside with the Kaufmans, nor did they raise, train or discipline him as they would have done with one of their own children. ${ }^{147}$ For this reason, the court concluded that there was no parent-child relationship between the petitioners and Huitzil as required by the statute and, therefore, affirmed the lower court's dismissal of the adoption petition. ${ }^{148}$

On the other hand, in In re the Adoption of Elizabeth P.S. by Eileen $C$., a New York court concluded that the parties had formed the requisite parent-child relationship. ${ }^{149}$ In that case, Eileen, a 49-year-old nun

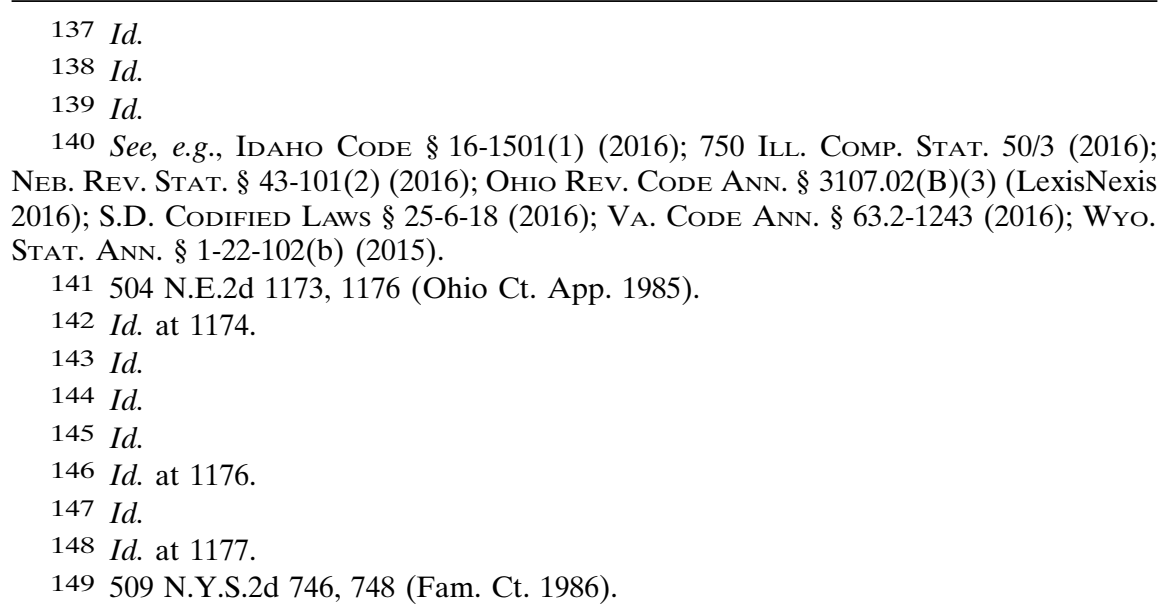


petitioned to adopt Elizabeth, a 48-year-old woman. ${ }^{150}$ Eileen met Elizabeth while working at a private facility for troubled females operated by her religious order. ${ }^{151}$ Eileen counseled Elizabeth, taught her to read and otherwise looked after her at the facility. ${ }^{152}$ When Eileen left the religious order on leave, she took Elizabeth with her. ${ }^{153}$ The two women maintained a mother-daughter relationship for more than twenty years. ${ }^{154}$ The court noted that the New York Court of Appeals had recently held that a parent-child relationship was necessary for one adult to adopt another. ${ }^{155}$ However, it concluded that, in this case, the relationship was not a sexual one, but rather amounted to a "healthy parentchild union within the meaning of Article VII of the Domestic Relations Law." 156

\section{ii. Consent of parents or spouses}

Some statutes require the consent of certain parties to the adoption or at least notice to them. Failure to do so may allow these parties to contest or annul the adoption. Depending on the particular state these parties may include the adoptee's parents, the adopter's spouse or, if the adoptee is married, the adoptee's spouse.

Most adoption statutes require the biological parents to be notified of an adoption and be given the opportunity to object or consent to it when the adoptee is a minor. However, a few states also require parental consent or notice when the adoptee is an adult. ${ }^{157}$ For example, in the Scott case, ${ }^{158}$ the lower court dismissed an adoption petition for failure to conform to the statutory requirements. ${ }^{159}$ On appeal, the court observed that Florida's adult adoption statute required that the petitioner provide the court with either "[w]ritten consent . . . executed by the natural parent or parents, if any, or proof of service of process ...

\footnotetext{
150 Id. at $746-47$.

151 Id. at 747.

152 Id.

$153 I d$.

154 Id. at 746.

155 Id. at 747 (citing In re Adoption of Robert Paul P., 471 N.E.2d 424, 425 (N.Y. 1984)).

156 Id. at 748 .

157 See, e.g., In re Adoption of Scott, 344 So. 2d 884, 884-85 (Fla. Dist. Ct. App. 1977); In re Adoption of an Adult by V.A., 683 A.2d 591, 595 (N.J. Super. Ct. Ch. Div. 1996). On the other hand, most courts have refused to impose a parental notification or consent requirement in the absence of a statutory provision. See Ala. Dep't of Human Res. v. B.V., 59 So. 3d 700, 708-09 (Ala. Civ. App. 2010); In re Adoption of Miller, 227 So. 2d 73, 75 (Fla. Dist. Ct. App. 1969); In re Adoption of Chaney, 887 P.2d 1061, 1064 (Idaho 1995); Bridges v. Nicely, 497 A.2d 142, 147-48 (Md. 1985).

158 See In re Scott, 344 So. $2 \mathrm{~d}$ at 884-85.

159 Id. at 885.
} 
showing notice has been served on the parent or parents ...."160 Since the petitioner failed to provide evidence of parental consent or notice, the court affirmed the lower court's dismissal of the adoption petition. ${ }^{161}$

Quite a few states require the consent of the adopter's spouse if the adopter is married. ${ }^{162}$ In re O'Keefe ${ }^{163}$ provides an interesting example of this. In that case, Isabella Jacobie, the widow of Walter Jacobie, sought to vacate his adoption of an adult woman named Helen O'Keefe. ${ }^{164}$ It appears that Walter had claimed to be a widower in his adoption petition. ${ }^{165}$ The Surrogate Court agreed that Isabella's consent was required and, therefore, vacated its earlier adoption order. ${ }^{166}$

The spousal consent requirement was also involved in the Adoption of Sewall case. ${ }^{167}$ In 1952, Charles Keeler, aged 72, adopted Eleanor Sewall, a 45-year-old widow and mother of two daughters. ${ }^{168}$ When Charles died in 1964, his will, executed shortly after the adoption, left his entire estate to Eleanor. ${ }^{169}$ Ellen Schaefer, a niece, contested the will and also sought to set aside the adoption decree, claiming fraud and undue influence. ${ }^{170}$ Leila Keeler, a former spouse, also argued that the adoption was invalid. ${ }^{171}$ Although Leila and Charles had obtained a Nevada divorce in 1943, Leila contended that the divorce was invalid and that she was still married to Charles at the time of his death. ${ }^{172}$ Since Leila did not consent to Eleanor's adoption as required by state law, she argued that the adoption should be nullified. ${ }^{173}$ Affirming the lower court, the California appeals court held that Leila's divorce was

$160 I d$. at 885 n.1 (quoting Fla. STAT. § 63.062(3)(b) (1975)).

161 Id. at 886

162 See, e.g., Alaska Stat. § 25.23.040(b) (2016); Ariz. Rev. Stat. Ann. § 148101(C) (2016); Cal. Fam. Code $§ 9301$ (West 2016); Conn. Gen. Stat. § 45a-734(c), (e) (2016); Fla. Stat. § 63.062(8)(a) (2016); Idaho Code $\S 16-1504(h)$ (2016); Kan. Stat. Ann. § 59-2113 (2015); Mont. Code Ann. § 42-4-403(1)(c) (2015); Neb. Rev. Stat. § 43-101(2) (2016); Nev. Rev. Stat. § 127.200(2) (2015); N.Y. Dom. Rel. Law $\S 110$ (McKinney 2016); N.C. Gen. Stat. § 48-5-102(a)(2) (2015); N.D. Cent. Code $\S 14-15-05(2)$ (2015); S.C. Code Ann. § 63-9-1120 (2016); Utah Code Ann. § 78B-6116(1)(a)(iii) (LexisNexis 2015); WIs. STAT. § 882.02 (2015).

163300 N.Y.S. 27, 30 (Sur. Ct. Saratoga Cty. 1937).

$164 I d$. at 28.

165 Id. at 29.

166 Id. at 31.

167 In re Adoption of Sewall, 51 Cal. Rptr. 367, 371 (Dist. Ct. App. 1966).

168 Id. at 370.

169 Id.

170 Id. at 371-72.

171 Id. at 371 .

172 Id.

173 Id. 
valid and, as such, she had no standing to contest the adoption. ${ }^{174}$ The court also concluded that Ellen did not have standing to challenge the adoption regardless of Leila's marital status, although as the closest blood relative of Charles, she could contest his will. ${ }^{175}$

Although a married adult can be adopted, ${ }^{176}$ a few states require that the adoptee's spouse consent to the adoption. ${ }^{177}$ For example, in McComesky's Adoption, ${ }^{178}$ the petitioner, a resident of the National Military Home in Dayton, Ohio, proposed to adopt an adult woman. ${ }^{179}$ The court observed that the adoption statute permitted the adoption of an adult, but required the consent of the adoptee's spouse if he or she was married. ${ }^{180}$ Since the adoption petition did not indicate whether the adoptee was married or not, and no spousal consent had been given, the court refused to approve the adoption. ${ }^{181}$

Another Pennsylvania case, In re Mullany's Adoption, ${ }^{182}$ provides a helpful gloss on the purpose behind the spousal consent requirement. In 1896, Ellen Euker adopted her adult nephew, Timothy Mullany. ${ }^{183}$ Mullany's parents died while he was very young and he lived with his aunt until he reached adulthood and married. ${ }^{184}$ Ellen Euker died intestate in 1900 and Timothy, who had taken his aunt's last name at the time of his adoption, claimed her entire estate as her son under the intestacy statute. 185 Realizing that Timothy's wife, Margaret, has not given her consent to the adoption in writing, Margaret gave the court a sworn statement that she had given her consent at the time of the adoption, though not in writing. ${ }^{186}$ The court permitted her to give her consent in this manner "nunc pro tunc." 187

Meanwhile, three of Ellen's siblings also claimed her estate, arguing that the court had no jurisdiction to grant Ellen's petition because

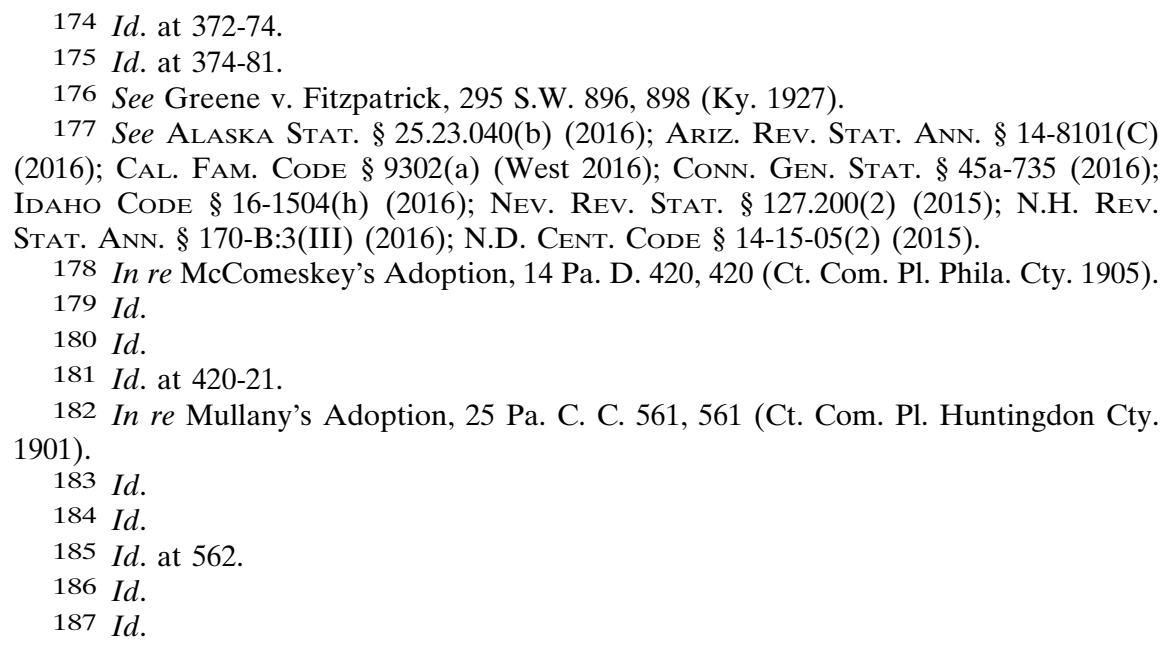


Timothy's wife, Margaret, had not consented in writing to the adoption. ${ }^{188}$ However, the court rejected this argument. It distinguished between the adoption of a minor and the adoption of an adult. ${ }^{189}$ In the case of a minor child, someone competent to contract, such as a parent or guardian, is needed to give the required consent because the child is not legally capable to doing do. ${ }^{190}$ However, an adult is capable of giving legal consent and no one else's consent is needed to give it validity. ${ }^{191}$ Because adoption imposes certain obligations on the part of the adoptee, the requirement that the adoptee's spouse consent to the adoption is intended solely to protect his or her interests. ${ }^{192}$ Accordingly, since Margaret's rights were the only one's affected by her failure to consent in the proper manner, the court reasoned that only she had standing to complain of any irregularity in the adoption procedure. ${ }^{193}$ For this reason, the court refused to revoke Timothy's adoption. ${ }^{194}$

\section{b. Restrictions and Prohibitions}

Most adult adoption statutes impose few restrictions on who may be adopted. In fact, it is not unusual for people to adopt close relatives, ${ }^{195}$ stepchildren ${ }^{196}$ or in-laws. ${ }^{197}$ However, a few states impose restrictions on who can adopt or be adopted. ${ }^{198}$ For example, some states

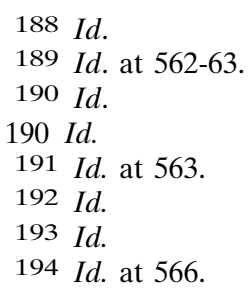
N.E.2d 301, 303 (Ind. Ct. App. 1983) (grandson); In re Succession of Caldwell, 38 So. 140, 140 (La. 1905) (niece); Evans v. McCoy, 436 A.2d 436, 438 (Md. 1981) (cousin); In re Adoption of Bertson, 206 N.W.2d 28, 29 (Minn. 1973) (mother); In re Tr. Created Under Agreement with Lane, 660 N.W.2d 421, 423 (Minn. Ct. App. 2003) (nephew); Hurt v. Noble, 817 P.2d 744, 745 (Okla. Civ. App. 1991) (grandchildren).

196 See In re Adoption of Chaney, 887 P.2d 1061, 1062 (Idaho 1995); Faville v. Burns, 960 N.E.2d 99, 102 (Ill. App. Ct. 2011); Satterfield v. Bonyhady, 446 N.W.2d 214, 215 (Neb. 1989); In re Adoption of an Adult, 683 A.2d 591, 591 (N.J. Super. Ct. Ch. Div. 1996); In re Estate of Griswold, 354 A.2d 717, 719 (Morris Cty. Ct. 1976); Hagaman v. Morgan, 886 S.W.2d 398, 400 (Tex. App. 1994). But see Hays v. Hays, 946 So. 2d 867, 869 (Ala. Civ. App. 2006) (holding that statute allowing adoption of adult stepchildren did not apply to husband's daughter after husband's death because stepmother-stepdaughter relationship no longer existed).

197 See In re Estate of Fortney, 611 P.2d 599, 600-01 (Kan. Ct. App. 1980) (wife's nephew).

198 See Honeycutt, supra note 124, at 173. 
have refused to allow one spouse to adopt another, at least for purposes of securing an inheritance, either by statute ${ }^{199}$ or by court decision. ${ }^{200}$ Similarly, at least a few courts have refused to allow adoption between unmarried heterosexual partners. ${ }^{201}$ In addition, in the past, at least one state refused to allow gay or lesbian couples to formalize their relationship by means of adoption. ${ }^{202}$

\section{i. Heterosexual relations between adopting parties}

One can argue that adoption of a lover is an "undesirable social use" of the adoption process. ${ }^{203}$ Nevertheless, there are few cases where courts have inquired very seriously about whether the adopting parties were engaged in a sexual relationship. In one instance, in Stevens v. Halstead, ${ }^{204}$ a New York court allowed the next of kin of the adopter to try to set aside an adoption on grounds of fraud and undue influence. ${ }^{205}$ The plaintiff contended that the adoptee, a 47-year-old married woman, was the mistress of the 70-year-old adopter. ${ }^{206} \mathrm{Al}-$ though the court did not hold that a sexual relationship per se was sufficient to invalidate an adoption, it did declare that "[s]urely it is against public policy to admit a couple living in adultery to the relation of parent and child." 207 Furthermore, the court continued, "[t]his meretricious relationship, and the undue influence which imposed the will of defendant on decedent, condemn the adoption." 208

The Rhode Island Supreme Court in In re Jones ${ }^{209}$ went even further and concluded that the existence of a sexual relationship was inconsistent with a valid adoption. In that case, a 30-year-old married man, Duncan Fraser, sought to adopt a 20 -year-old woman named Karen Jones. ${ }^{210}$ Duncan was apparently the father of Karen's child as well as

\footnotetext{
199 See Mont. Code Ann. § 42-4-402(1) (2015); Nev. Rev. Stat. § 127.190(1) (2015); N.C. Gen. Stat. § 48-5-101 (2016).

200 See In re Tr. Created by Belgard, 829 P.2d 457, 460 (Colo. App. 1991); Minary v. Citizens Fid. Bank \& Tr. Co., 419 S.W.2d 340, 341, 344 (Ky. 1967); Pennington v. Citizens Fid. Bank \& Tr. Co., 390 S.W.2d 671, 672 (Ky. 1965). But see Successions of Plummer v. Plummer, 577 So. 2d 751, 753, 755 (La. Ct. App. 1991).

201 See Stevens v. Halstead, 168 N.Y.S. 142, 143-44 (App. Div. 1917); In re Jones, 411 A.2d 910, 911 (R.I. 1980).

202 See In re Adoption of Robert Paul P., 471 N.E.2d 424, 425 (N.Y. 1984).

203 See Walter Wadlington, Adoption of Adults: A Family Law Anomaly, 54 CorNELL L. REV. 566, 579 (1969).

204 See Stevens, 168 N.Y.S. at 142.

205 Id. at 142-44.

206 Id. at 142.

207 Id. at 144.

$208 I d$.

209 In re Jones, 411 A.2d 910, 910-11 (R.I. 1980).

$210 \mathrm{Id}$. at 910.
} 
two other children. ${ }^{211}$ The probate court denied the adoption petition and the superior court affirmed this decision. ${ }^{212}$ Karen, who elected to pursue the matter further despite having married someone other than Duncan, argued that the adult adoption statute did not permit the adoption to be denied as long as the parties complied with its procedural requirements. ${ }^{213}$ Thus, she declared, the court was not allowed to consider "in any manner, shape, or fashion her past adulterous association with Duncan and its potentially incestuous impact." 214

On appeal, the Rhode Island Supreme Court declared that the probate judge could exercise discretion where one adult seeks to adopt another. ${ }^{215}$ It endorsed the comments of the lower court, which had declared that

[i]t may be that public morality in our community has reached a low ebb. However, it is the opinion of the Court that it has not yet descended to such a nadir as to require a probate or superior court judge to implement an adoption between persons whose relationship is essentially that of paramours. ${ }^{216}$

In effect, the appeals court added a morals provision to Rhode Island's adult adoption requirements.

\section{ii. Gay or lesbian adopting parties}

While a few courts have refused to allow one gay or lesbian partner to adopt the other, ${ }^{217}$ most have concluded that such adoptions are valid. ${ }^{218}$ In re Adoption of Robert Paul P. ${ }^{219}$ a decision by the New York Court of Appeals, reflects the minority view that gay and lesbian adoptions are not valid. In that case, the lower court refused to allow a 57 -year-old man to adopt his 50-year-old partner. ${ }^{220}$ The admittedly gay couple had lived together for more than 25 years. 221 They sought to formalize their relationship through adoption for social, financial and emotional reasons. ${ }^{222}$ However, the lower court concluded that the par-

211 Id.

212 Id. at 911.

213 Id. at 910-11.

$214 I d$. at 911.

215 Id.

216 Id.

217 See In re Adoption of Robert Paul P., 471 N.E.2d 424, 425 (N.Y. 1984).

218 See In re Adoption of Swanson, 623 A.2d 1095, 1099 (Del. 1993); In re Adoption of Patricia S., 976 A.2d 966, 972 (Me. 2009); Ex parte Libertini, 224 A.2d 443, 444 (Md. 1966); See also In re Adoption of Spado, 912 A.2d 578, 579 (Me. 2007).

219 In re Robert Paul P., 471 N.E.2d at 424-27.

$220 I d$. at 425.

221 Id.

222 Id. 
ties were attempting to use the adoption process to achieve objectives that were more appropriately achieved by marriage, wills and business contracts and, furthermore, that there was no parent-child relationship between them. ${ }^{223}$ This decision was upheld by the Appellate Division. ${ }^{224}$

The Court of Appeals affirmed the decision of the lower courts. ${ }^{225}$ The appeals court began by citing the familiar maxim that adoption should imitate nature. ${ }^{226}$ That is, adoption is intended to create a relationship between the adopter and adoptee that replicates that of parent and child. ${ }^{227}$ Citing Stevens v. Halstead, ${ }^{228}$ the court declared that adoption was not a "quasi-matrimonial vehicle" and could not be used as a means of providing a legal sanction for an illicit sexual relationship, whether it be heterosexual or homosexual. ${ }^{229}$ Furthermore, the court opined that

any such sexual intimacy is utterly repugnant to the relationship between child and parent in our society, and only a patently incongruous application of our adoption laws-wholly inconsistent with the underlying public policy of providing a parent-child relationship for the welfare of the child would permit the employment of adoption as the legal formalization of an adult relationship between sexual partners under the guise of parent and child. ${ }^{230}$

Consequently, the court concluded that the adoption statute, as presently written, did not permit an adoption that was manifestly inconsistent with a parent-child relationship. ${ }^{231}$

In contrast, courts in Maryland and Delaware have allowed samesex couples to adopt. Ex Parte Libertini ${ }^{232}$ involved the proposed adoption by an unmarried 56-year-old woman of a 35-year old unmarried woman. ${ }^{233}$ Both women were members of the military. ${ }^{234}$ The purpose of the adoption was to facilitate inheritance and promote "maternal

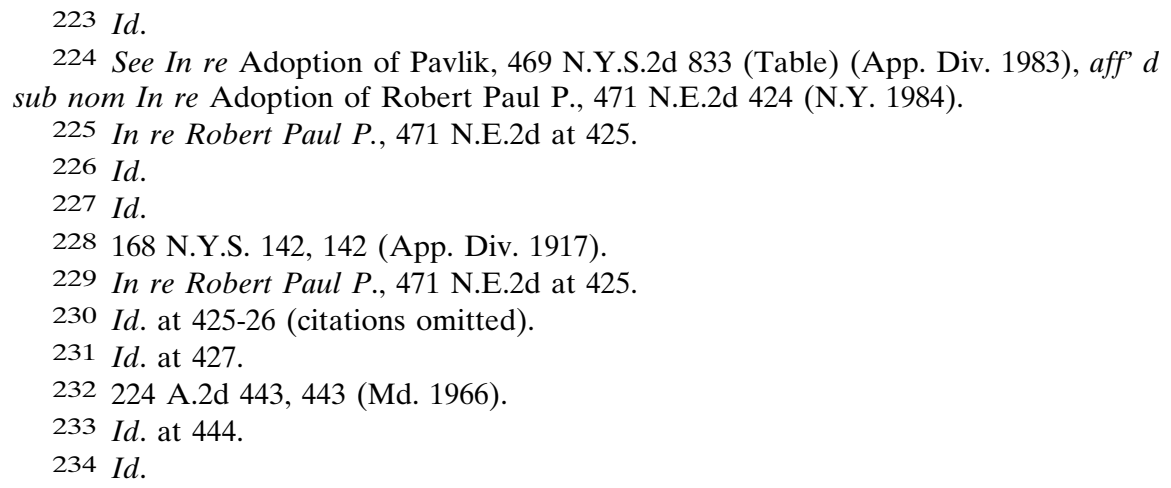


feeling." 235 However, the lower court summarily dismissed the petition, contending that "to declare a person a legal child of an unmarried woman is to declare her to be illegitimate."236 For good measure, the lower court added that the proposed adoption was "a perversion of the entire adoptive process" and would serve no useful purpose. ${ }^{237}$

However, the appeals court determined that the state's adoption law did not require that an adoptive parent be married. ${ }^{238}$ Moreover, it acknowledged that the law in Maryland permitted adult adoption for purposes of inheritance and did not change the "social or domestic relationship of either party." 239 Consequently, the court rejected the lower court's assumption that the adoption of an adult by an unmarried adult did not result in illegitimacy. ${ }^{240}$ Therefore, the court concluded that, in the absence of any evidence of wrongdoing or improper motive, the lower court improperly dismissed the parties' petition. ${ }^{241}$

In In re Adoption of Swanson, ${ }^{242}$ Richard Sorrels sought to adopt his companion of 17 years. ${ }^{243}$ At the time of the proposed adoption, Sorrels was 66 years old and Swanson was 51.244 According to the petitioners, the adoption was intended "formalize the close emotional relationship that had existed between them for many years and to facilitate their estate planning." 245 Insofar as this latter goal was concerned, the parties hoped that their adoption would frustrate claims against their respective estates from remote family members. ${ }^{246}$ As in the Robert Paul P. case, the lower court denied the petition because there was no pre-existing parent-child relationship between the parties. ${ }^{247}$

The issue on appeal was whether a pre-existing family relationship between the parties was required for an adult adoption. ${ }^{248}$ The court began by pointing out that the Delaware adult adoption statute did not expressly require parties to an adoption to prove that a family relationship existed. ${ }^{249}$ In addition, it observed that the statute's provisions for adult adoption differed from those concerned with the adoption of mi-

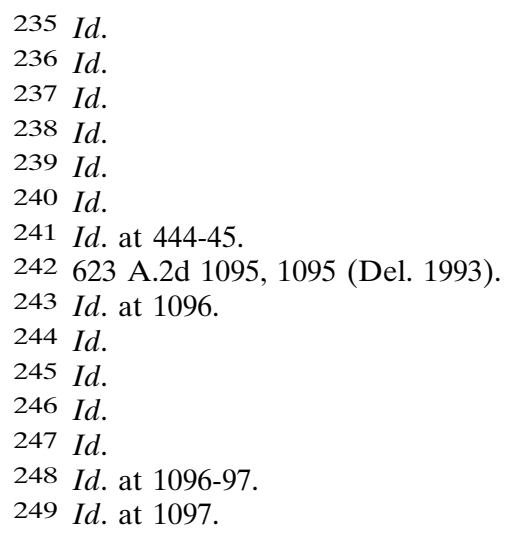


nors. ${ }^{250}$ The latter contained provisions for the investigation and supervision of prospective placements, while the former did not.251 In addition, the court noted other jurisdictions' limited inquiries into the parties' motives in adult adoption cases and that most of them permitted adoptions for the purpose of creating inheritance rights. 252 The court concluded by declaring that the Delaware statute also reflected a legislative intent to allow adoption for economic reasons and also to restrict judicial inquiries into any ulterior motives the adopting parties might have. ${ }^{253}$

In 2015, the United States Supreme Court decided Obergefell $v$. Hodges, in which it upheld the validity of same sex marriages. ${ }^{254}$ This ruling largely does away with the need for same sex couples to rely on adult adoption as a substitute for marriage.

\section{iii. Fraudulent motives}

A few courts have disapproved of adult adoptions that were done solely to affect inheritance rights. ${ }^{255}$ However, other states have allowed adoptions for inheritance purposes to take place. For example, in Harper v. Martin, ${ }^{256}$ Vera Harper, who was suffering from terminal cancer, adopted 47-year-old Jim Harper for the sole purpose of making him her heir. ${ }^{257}$ Upholding Jim's right to inherit, the court distinguished between adopting in order to affect rights under a testamentary instrument and adopting in order to make someone an heir under the laws of intestate succession. ${ }^{258}$ In the former case, the adoption was intended to thwart the intent of the testator and cheat the intended beneficiaries; in the latter case, however, the decedent had no plan of disposition and, therefore, suffered no injury. ${ }^{259}$

\section{c. A Critique of Existing Adult Adoption Law}

The foregoing discussion suggests that existing adult adoption laws are often cluttered with baggage imported from earlier statutes centered around the adoption of minors. For example, requiring a pre-existing parent-child relationship unnecessarily restricts the availability of adoption for many adults without promoting any public policy. Likewise, re-

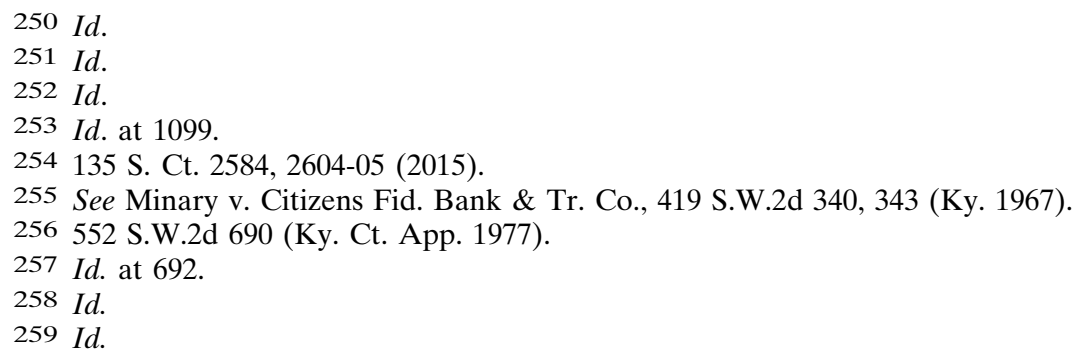


quiring the consent of parents, or even spouses, is hard to justify when the adoption does not impose a duty of support on the adoptive parent or necessarily confer any legal rights on the adoptee. Furthermore, prohibiting one adult lover from adopting the other can hardly be justified on the theory that the parties are somehow parent and child. While these sorts of requirements, restrictions and prohibitions are appropriate when the adoptee is a child, they serve no legitimate purpose when the parties are competent adults.

\section{Adult Adoption and Intestacy}

Adult adoptions are frequently used as a means of transferring property to another at death. As such, adoption is an appropriate form of will substitute as far as the parties to the adoption are concerned. However, it is more troublesome when used to effectuate a transfer of property from a third party to the adoptee. This section examines various aspects of adoption and intestacy. The discussion starts with the right of an adopted child to inherit from adoptive parents and other members of the adoptive family. The next issue involves the right of an adopted child to inherit under the laws of descent and distribution from biological parents and other biological family members. As there are relatively few reported cases on this issue involving adult adoptions, discussion will initially focus on the adoption of minors.

A. The Right of Adopted Children to Inherit from Members of Their Adoptive Family

\section{The Right of Adopted Children to Inherit from Their Adoptive Parents}

Although some of the earlier decisions declared that an adopted child's right to inherit from his or her adoptive parents was wholly contractual in nature, ${ }^{260}$ most courts have since concluded that an adopted child's inheritance rights derives from the state's adoption statute. ${ }^{261}$ They have also found that virtually all adoption statutes either expressly or impliedly allow adopted children to inherit from their adoptive parents. ${ }^{262}$ A California decision, In re Newman's Estate, illustrates this

260 See Merritt v. Morton, 136 S.W. 133, 134 (Ky. 1911); In re Eddins' Estate, 279 N.W. 244, 245 (S.D. 1938).

261 See In re Grinnell's Estate, 220 N.W. 583, 585 (Neb. 1928).

262 See, e.g., In re Williams' Estate, 36 P. 407, 410 (Cal. 1894); In re Newman's Estate, 16 P. 887, 888-89 (Cal. 1888); Glos v. Sankey, 36 N.E. 628, 634 (Ill. 1893); Atchison v. Atchison's Ex'rs, 12 S.W. 942, 943 (Ky. 1890); Power v. Hafley, 4 S.W. 683, 684 (Ky. 1887); Buckley v. Frazier, 27 N.E. 768, 769 (Mass. 1891); In re Grinnell's Estate, 220 N.W. at 585; Hopkins v. Hopkins, 195 N.Y.S. 605, 606 (App. Div. 1922), aff' d 142 N.E. 277 
principle nicely. ${ }^{263}$ Ruling that an adopted child was entitled to inherit from his adoptive parents, the court reviewed the adoption provisions of the California Civil Code, sections 227 and 228, as well as the state's statute on descent and distribution, section $1386 .{ }^{264}$ First, the court observed that section 227 stated that the adoption order must declare that the adopted child "shall thenceforth be regarded and treated in all respects as the child of the person adopting." 265 Furthermore, section 228 provided that once the adoption proceeding was completed, the parties "shall sustain towards each other the legal relation of parent and child, and have all the rights, and be subject to all the duties of that relation." 266 The court concluded that the language of these provisions was sufficiently "general and comprehensive" to include the right to inherit from the adoptive parent in the same manner as a natural child. ${ }^{267}$

\section{The Right of Adopted Children to Inherit from the Ancestors of Their Adoptive Parents}

There was a split of authority, particularly among the older cases, as to whether an adopted child can inherit from adoptive grandparents or other ancestors. In the absence of express statutory language, courts typically relied on a number of rationales to deny adoptees the right to inherit. 268 For example, it was said that the adoption process was contractual in nature. ${ }^{269}$ According to this theory, the contracting parties should not be able to affect the rights of those who were not parties to the contract. 270 Another rationale emphasized that descent and distribution were historically restricted to the decedent's blood line. ${ }^{271}$ How-

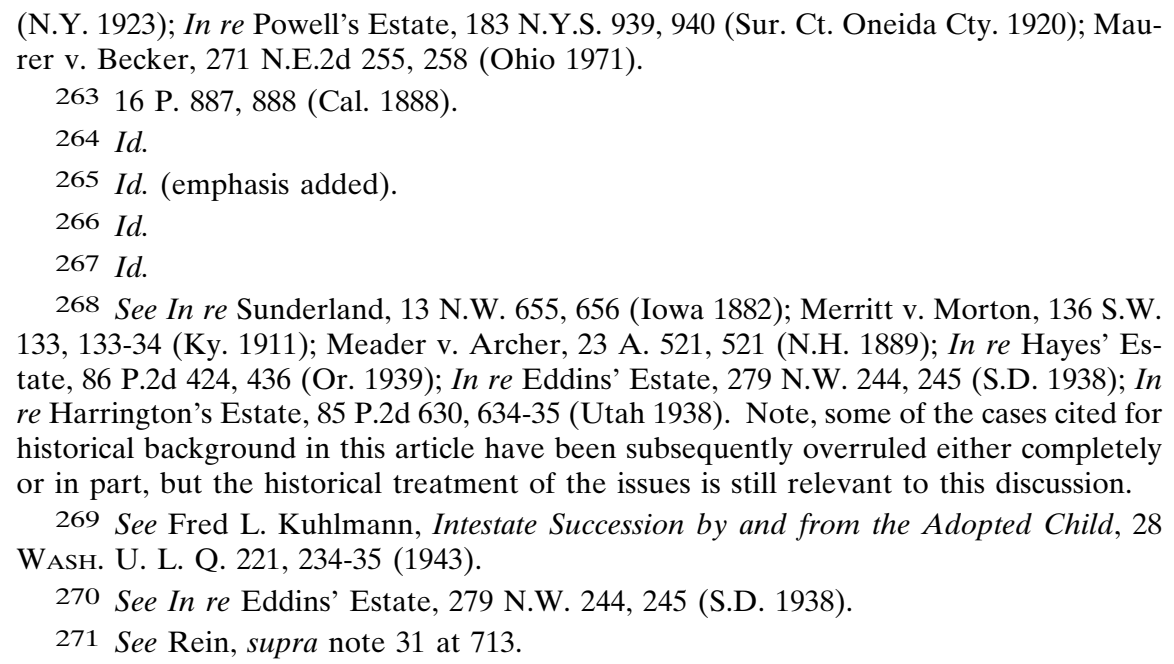


ever, nowadays, most courts have allowed adopted children to inherit from ancestors of their adoptive parents. ${ }^{272}$

\section{The Right of Adopted Children to Inherit from Collateral Relatives of Their Adoptive Parents}

There is also a split of authority over whether adopted children can inherit from the collateral relatives of their adoptive parents. Many of the older cases refused to recognize such inheritance rights; ${ }^{273}$ however the trend now seems to be moving in the direction of allowing adopted children to inherit. ${ }^{274}$ This trend is based on the notion that an adopted child, like the natural offspring of his biological parents, not only acquires new parents, but may also acquire new siblings, grandparents, aunts, uncles or cousins. ${ }^{275}$

\section{The Right of Adopted Children to Inherit from Their Biological Parents}

Up until the second half of the twentieth century, most courts permitted adopted children to inherit from and through their biological parents. $^{276}$ The courts of that period expressed various rationales in support of this position. One rationale was that statutes of descent and distribution based inheritance rights almost exclusively on consanguin-

272 See In re Estate of Darling, 159 P. 606, 608-09 (Cal. 1916); Riley v. Day, 129 P. 524 (Kan. 1913); In re Taylor's Estate, 285 N.W 538, 541 (Neb. 1939).

273 See Keegan v. Geraghty, 101 Ill. 26, 35-36 (1881); Batcheller-Durkee v. Batcheller, 97 A. 378, 380 (R.I. 1916).

274 See McClure v. Noble, 602 So. 2d 377, 378 (Ala. 1992); In re Estate of Carlton, 348 So. 2d 896, 896 (Fla. Dist. Ct. App. 1977); see also Anne Wiseman French, When Blood Isn't Thicker Than Water: The Inheritance Rights of Adopted-out Children in New York, 53 Brook. L. Rev. 1007, 1034-35 (1988).

275 See Rein, supra note 31 at 721-22.

276 See, e.g., In re Moore's Estate, 47 P.2d 533, 535 (Cal. Dist. Ct. App. 1935); In re Wilson's Estate, 33 P.2d 969, 970 (Colo. 1934); In re Estate of Levy, 141 So. 2d 803, 805 (Fla. Dist. Ct. App. 1962); Sears v. Minchew, 93 S.E.2d 748, 750-51 (Ga. Ct. App. 1956); In re Tilliski's Estate, 56 N.E.2d 481, 487 (Ill. App. Ct. 1944); Holmes v. Curl, 178 N.W. 406, 408 (Iowa 1920); Wagner v. Varner, 50 Iowa 532, 534 (1879); In re Bartram's Estate, 198 P. 192, 193 (Kan. 1921); Dreyer v. Schrick, 185 P. 30, 33 (Kan. 1919); Roberts v. Roberts, 199 N.W. 581, 581 (Minn. 1924); In re Estate of Jones, 687 So. 2d 1171, 1178 (Miss. 1996); Alack v. Phelps, 230 So. 2d 789, 793 (Miss. 1970); Sledge v. Floyd, 104 So. 163, 164-65 (Miss. 1925); In re Kay's Estate, 260 P.2d 391, 395 (Mont. 1953); In re Estate of Wulf, 167 N.W.2d 181, 183 (Neb. 1969); Nickell v. Gall, 229 A.2d 511, 513 (N.J. 1967); Estate of Ballantine v. Close, 81 N.W.2d 259, 261-62 (N.D. 1957); Sorenson v. Churchill, 212 N.W. 488, 489 (N.D. 1927); Stark v. Watson, 359 P.2d 191, 194 (Okla. 1961); In re Benner's Estate, 166 P.2d 257, 259 (Utah 1946); In re Roderick's Estate, 291 P. 325, 327 (Wash. 1930). 
ity. ${ }^{277}$ For example, in In re Estate of Wulf, an adopted child sought to inherit from the estate of her biological father. ${ }^{278}$ Upholding the lower court's decision that the adopted child could inherit, the appellate court emphasized the importance of the bloodline in descent and distribution. ${ }^{279}$

Another justification of allowing an adopted child to inherit was based on the notion that the adoption process should not strip the child of his natural inheritance rights when the child was unable to withhold his consent. ${ }^{280}$ However, the most popular approach to the issue of inheritance rights relied on principles of statutory construction. Essentially, courts that employed this approach concluded that adoption statutes should be liberally construed insofar as they conferred rights on the adopted child, but should not be interpreted to take away existing rights unless the legislative intent to do so was clear and explicit. ${ }^{281}$ This principle is illustrated by Estate of Levy, where the court declared that the state's adoption statute "does not attempt to take away an adoptee's preexisting right of inheritance from his natural parents or from his natural kindred. It only limits the right of the natural parents to inherit from the adopted child. No other limitation appears in the statute."282

However, an interesting issue arises in cases where an adopted child is also related by blood to the decedent, usually an ancestor such as a grandparent. Assuming that the adoptive child can directly inherit from his adoptive parent by virtue of the adoption statute, can he take an additional share under the statute of descent and distribution based on the blood relationship between the adopted child and the decedent? Some jurisdictions have accepted this "dual inheritance" theory, ${ }^{283}$ but others have rejected it because it treated adopted children differently

277 See In re Wilson's Estate, 33 P.2d at 969-70; In re Levy, 141 So. 2d at 804; Alack, 230 So. 2d at 792-93; In re Wulf, 167 N.W.2d at 182; Estate of Ballantine, 81 N.W.2d at 262; Sorenson, 212 N.W. at 489.

278 See In re Wulf, 167 N.W.2d at 182. The claimant, Anne Marie, was adopted as a child by her father's sister and husband. During his lifetime, Anne Marie stayed in close contact with her biological father, Fred Wulf. Id.

$279 I d$.

280 See, e.g., In re Wilson's Estate, 33 P.2d at 971; In re Bartram's Estate, 198 P. at 193; Alack, 230 So. 2d at 792; Estate of Ballantine, 81 N.W.2d at 263; Sorenson, 212 N.W. at 489; Stark, 359 P.2d at 195.

281 See Wagner, 50 Iowa at 534; In re Bartram's Estate, 198 P. at 193; Dreyer, 185 P. at 33; Roberts, 199 N.W. at 581; Sledge, 104 So. at 165; Stark, 359 P.2d at 194; In re Benner's Estate, 166 P.2d at 259 ; In re Roderick's Estate, 291 P. at 327.

282 See In re Estate of Levy, 141 So. 2d. 803, 805-06 (Fla. Dist. Ct. App. 1962).

283 See In re Wilson's Estate, 33 P.2d 969, 971 (Colo. 1934); Wagner v. Varner, 50 Iowa 532, 532 (1879); In re Bartram's Estate, 198 P. 192, 193 (Kan. 1921); Jenkins v. Jenkins, 990 So. 2d 807, 812-13 (Miss. Ct. App. 2008); In re Benner's Estate, 166 P.2d 257, 259 (Utah 1946). 
than natural children of the adoptive parents. ${ }^{284}$ The modern trend is to deny an adopted child to right to inherit from his or her biological parents. $^{285}$ Today, adoption statutes seek to promote the best interests of the child by totally transferring the child to a new family with a "fresh start" as a full-fledged member of the adoptive family. ${ }^{286}$ When a child is adopted, the rights of his or her biological parents are terminated, and the child receives a new birth certificate in the name of the adoptive family. ${ }^{287}$

\section{The Right of Adopted Children to Inherit from Their Biological Relatives}

With shift in emphasis from bloodlines to the integration of the adopted child into the adoptive family, it is not surprising that recent statutes, and the cases interpreting them, have not allowed adopted children to inherit through representation from their biological relatives. ${ }^{288}$ Hall $v$. Vallandingham provides a good illustration of this approach. ${ }^{289}$ In that case, Earl Vallandingham died in 1956, survived by his spouse and four children. ${ }^{290}$ The widow remarried two years later and her new husband, Jim Kilgore, adopted the children.291 In 1983, Earl's brother, William, died intestate, survived by a number of siblings and the children of siblings who had predeceased him. ${ }^{292}$ Earl's children appealed the trial court's ruling that their adoption by Kilgore precluded them from receiving a share of William's estate. ${ }^{293}$ The court observed that at the time of their adoption, the applicable statute clearly gave Earl's children the right to inherit from his relatives. ${ }^{294}$ However, in 1963, the

284 See Billings v. Head, 111 N.E. 177, 177 (Ind. 1916); Delano v. Bruerton, 20 N.E. 308, 309 (Mass. 1889); Young v. Bridges, 165 A. 272, 275-76 (N.H. 1933); Morgan v. Reel, 62 A. 253, 256-57 (Pa. 1905).

285 See In re Garay, 518 N.Y.S.2d 723, 728-29 (Sur. Ct. Kings Cty. 1987); see also N. Danette Parkins, Comment, Inheritance Rights Affected by Adoption: The Need for Statutory Reform, 26 IDAHO L. REv. 529, 536 (1989-90).

286 See Rein, supra note 31, at 713; Messler, supra note 3, at 1046.

287 See Peter T. Wendel, The Succession Rights of Adopted Adults: Trying to Fit a Square Peg Into a Round Hole, 43 Creighton L. Rev. 815, 834 (2010).

288 See, e.g., In re Estate of Calhoun, 282 P.2d 880, 881 (Cal. 1955) (brother); In re Estate of McQuesten, 578 A.2d 335, $338-39$ (N.H. 1990) (grandmother); Hall v. Vallandingham, 540 A.2d 1162, 1164-65 (Md. 1988) (uncle); In re Estate of Carlson, 457 N.W.2d 789, 791 (Minn. Ct. App. 1990) (cousins); but see In re Harrington's Estate, 85 P.2d 630, 634-35 (Utah 1938); In re Estates of Donnelly, 502 P.2d 1163, 1164 (Wash. 1973) (grandfather).

289540 A.2d 1162 (Md. 1988).

290 Id. at 1163.

$291 \mathrm{Id}$.

292 Id.

293 Id.

294 Id. at 1164. 
legislature enacted a new statute which provided that adopted children would lose all rights of inheritance from their parents, as well as from their collateral and lineal relatives. ${ }^{295}$ According to the court, the current statute, which replaced the 1963 act, retained this prohibition against inheritance. ${ }^{296}$ This prohibition served two purposes: First, it removed the superior status that adoptive children would have if they were allowed to inherit from both their biological and their adoptive families. ${ }^{297}$ Second, the court declared that adoption should be treated as a "rebirth" into a new relationship, which results in a "clean-cut severance of the natural bloodline."298 Accordingly, the Maryland appellate court affirmed the lower court's judgment. ${ }^{299}$

\section{B. The Right of Third Parties to Inherit from or through Adoptees}

If adopted children are allowed to inherit from their adoptive parents and other relatives, should descendants of these adopted children possess similar rights of inheritance? Until recently, the weight of authority favored inheritance rights in such cases. ${ }^{300}$ Some courts also allowed descendants of adopted children to inherit from ancestors and collateral relatives of their adoptive parents. ${ }^{301}$ While the majority of decisions now allow adoptive parents to inherit from their adoptive children, ${ }^{302}$ there is a split of authority insofar as the inheritance rights of relatives of the adoptive parents are concerned. ${ }^{303}$ Finally, although earlier cases sometimes permitted biological parents or other relatives

\footnotetext{
$295 I d$.

296 Id. at $1164-65$.

297 Id.at 1164.

298 Id.

299 Id. at 1165.
}

300 See Power v. Hafley, 4 S.W. 683, 684-85 (Ky. 1887); In re Cook's Estate, 79 N.E. 991, 993 (N.Y. 1907); In re Estate of Seaman, 583 N.E.2d 294, 297 (N.Y. 1991); In re Estate of Edwards, 273 N.W.2d 118, 119 (S.D. 1978).

301 See Brooks Bank \& Tr. Co. v. Rorabacher, 171 A. 655, 658 (Conn. 1934); Wagner v. Varner, 50 Iowa 532, 534 (1879); Atchison v. Atchison's Ex'rs, 12 S.W. 942, 943 (Ky. 1890); Batchelder v. Walworth, 82 A. 7, 13 (Vt. 1912).

302 See Wright v. Wysowatcky, 363 P.2d 1046, 1049 (Colo. 1961); but see In re Jobson's Estate, 128 P. 938, 940 (Cal. 1912); Burger v. Frakes, 25 N.W. 735, 735 (Iowa 1885); Mancino v. Smith, 201 N.E.2d 93, 96 (Ohio Prob. Ct. Cuyahoga Cty. 1964); Hood v. Hatfield, 383 P.2d 1021, 1023 (Or. 1963); Hole v. Robbins, 10 N.W. 617, 619 (Wis. 1881).

303 See Phelan v. Conron, 81 N.E.2d 525, 528 (Mass. 1948) (recognizing the right to inherit); Willson v. Carmichael, 665 S.W.2d 52, 55 (Mo. Ct. App. 1984) (same); In re Estate of Neil, 191 N.W.2d 448, 451 (Neb. 1971) (same); In re Estate of Gillin, 773 A.2d 270, 271(Vt. 2001) (same); In re Loakes' Estate, 32 N.W.2d 10, 12 (Mich. 1948) (same); Upson v. Noble, 35 Ohio St. 655, 658-59 (1880) (rejecting the right to inherit); In re Frazier's Estate, 177 P.2d 254, 264 (Or. 1947) (same); In re Edwards, 273 N.W.2d at 119 (same). 
to inherit from or through adopted children, ${ }^{304}$ the weight of authority has now shifted toward the denial of such inheritance rights. 305

\section{Inheritance Rights of Adult Adoptees}

Although almost all states have enacted statutes to permit adult adoption, only a few adoption statutes specifically address the issue of adult adoption and intestate succession. ${ }^{306}$ The rest do not distinguish between the adoption of adults and minors but instead leave the determination of inheritance rights for adult adoptees to the courts. ${ }^{307}$ However, the Uniform Probate Code provides some guidance. Section 2-118 states that "a parent-child relationship exists between an adoptee and the adoptee's adoptive parent or parents." 308 Section 2-115 defines "adoptee" broadly as "an individual who has been adopted" without distinguishing between adults and minors. ${ }^{309}$ This is further clarified by a comment to section 2-115 which declares that the term "adoptee is not limited to an individual who is adopted as a minor but includes an individual who is adopted as an adult." 310 Finally, according to section 2116 , if there is a parent-child relationship, "the parent is a parent of the child and the child is a child of the parent for the purpose of intestate succession." 311 This suggests that an adult adoptee not only can inherit from his or her adoptive parents but may inherit through them as well by representation. ${ }^{312}$

In the absence of explicit statutory guidance, courts tend to treat adult adoptees the same as minors as far as inheritance rights are concerned. ${ }^{313}$ Thus, the adopted adult may inherit from his or her adopted parents in the same manner as an adopted minor child. This approach is

304 See Baker v. Clowser, 138 N.W. 837, 840 (Iowa 1912); Dodson v. Ward, 240 P. 991, 994 (N.M. 1925).

305 See Alexander v. Lamar, 3 S.E.2d 656, 658-59 (Ga. 1939); Swick v. Coleman, 75 N.E. 807, 808-09 (Ill. 1905); Humphries v. Davis, 100 Ind. 274, 282 (1885); In re Estate of Mills, 374 N.W.2d 675, 677 (Iowa 1985); In re Yates' Estate, 196 P. 1077, 1077 (Kan. 1921); Shepherd v. Murphy, 61 S.W.2d 746, 748-49 (Mo. 1933); In re Enyart's Estate, 218 N.W. 89, 91-92 (Neb. 1928); In re Fodor, 117 N.Y.S.2d 331, 333 (Sur. Ct. Bronx Cty. 1952); In re Hollstein's Estate, 295 N.Y.S. 598, 599 (App. Div. 1937); Ryan v. Sexton, 181 N.Y.S. 10, 11-12 (App. Div. 1920); In re Havsgord's Estate, 147 N.W. 378, 380 (S.D. 1014); Kummer v. Donak, 715 S.E.2d 7, 9 (Va. 2011); In re Estate of Kirkpatrick, 77 P.3d 404, 409 (Wyo. 2003); see also Ratliff, supra note 6, at 1781.

306 See Ala. Code $\S 26-10$ A-6 cmt. (2011); Ind. Code § 29-1-6-1(d) (2011).

307 See Ratliff, supra note 6, at 1792.

308 Unif. Probate Code § 2-118(a) (Unif. Law Comm'n 2010).

309 Id. § 2-115(1).

310 Id. $\$ 2-115 \mathrm{cmt}, 8$.

311 Id. § 2-116.

312 See Ratliff, supra note 6, at 1791.

313 Id. at 1781. 
exemplified by Tinney $v$. Tinney. ${ }^{314}$ In 1990, Ruth Tinney, who was 84 years old at the time, adopted Kevin Koellisch, then 38 years old, in an adult adoption proceeding. ${ }^{315}$ She died intestate in 1995, survived by Kevin and her biological son, Donald. 316 Kevin claimed one-half of Ruth's estate and Donald sought a declaratory judgment, contending that, unlike minors, adult adoptees could not inherit from their adoptive parents. ${ }^{317}$ The lower court held in Kevin's favor and Donald appealed. ${ }^{318}$ Reviewing various statutes, the appellate court concluded that they were "intended to integrate adopted children into family units and thus promote the public interest in the preservation of the family" and as such, should be "liberally construed in favor of the adopted child."319 Finally, while acknowledging that the legislature had distinguished between minors and adults as far as adoption requirements were concerned, it made no distinction between their inheritance rights. 320

An early case, First National Bank of St. Petersburg v. Mott, provides an exception to this principle. ${ }^{321}$ The case involved a dispute between an adopted child and the widow of her adopted father and her two minor children. ${ }^{322}$ The decedent, Samuel E. Doan, and his wife adopted Mae Mott, a married woman, who had lived with them in Connecticut as a member of their family. ${ }^{323}$ Mae argued that she should inherit a share of Samuel's estate as if she were his natural daughter. ${ }^{324}$ The lower court upheld Mae's claim and Samuel's widow and children appealed. ${ }^{325}$ The Florida Supreme Court noted that the state's adoption statute provided that "[a]ny child adopted by any person under the provisions of this law shall be declared the child and heir-at-law of the person applying for his adoption." 326 However, the court declared that the word "child" ordinarily meant a minor, not an adult. ${ }^{327}$ Therefore, it concluded that Mae, as an adult adoptee, was not entitled to inherit from her adoptive parent. 328

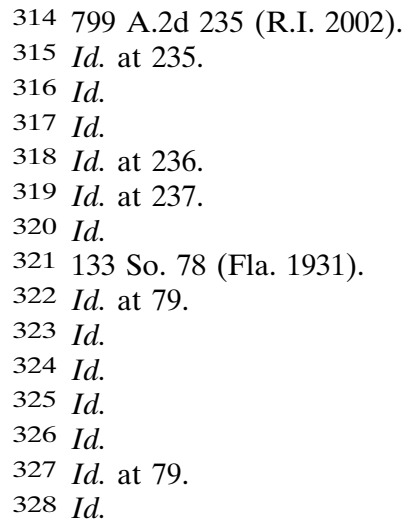


Most states also allow the issue of an adopted child to inherit from their adoptive parents as well. ${ }^{329}$ Adams v. Slater ${ }^{330}$ is illustrative of this view. In 1949, Frances and Anna Belle Rinard, a married couple, adopted Winona Jane Whitaker, a 26-year-old niece of Anna Belle. ${ }^{331}$ Winona Jane married Richard Strasser a few months later and gave birth to a daughter, Dianna Strausser, in $1950 .^{332}$ Winona Jane died in 1956, survived by her husband, her daughter and her adoptive mother. ${ }^{333}$ In 1958, Anna Belle died intestate, survived by Dianna and fifteen brothers, sisters and other collateral relatives. ${ }^{334}$ Dianna claimed to be her adoptive grandmother's sole heir, a claim that was disputed by Anna Belle's blood relatives. ${ }^{335}$ The lower court ruled in favor of Dianna. ${ }^{336}$

To support their claim, Anna Belle's relatives contended that the revised version of the state probate code limited the inheritance rights of adopted adults. ${ }^{337}$ The court in Scott v. Scott ${ }^{338}$ had concluded that section 6-208(a) of the revised probate code, which declared that "a child legally adopted during his minority ... shall cease to be treated as the child of his natural parents ... for purposes of intestate succession . . " "339 implicitly repealed a provision of the 1946 code which allowed an adopted child to inherit from his or her natural parent. ${ }^{340}$ However, the court in Adams held that section 6-208(b) had not repealed an earlier provision that declared that an adopted adult would be treated as the child of his natural parents for purposes of intestate succession, but added the words "except that he shall in addition be entitled to inherit as a child from the adopting parent or parents." 341 In other words, the revised probate code provided that all adopted children could inherit from their adopted parents, but adopted adults could also inherit through their adopted parents. ${ }^{342}$

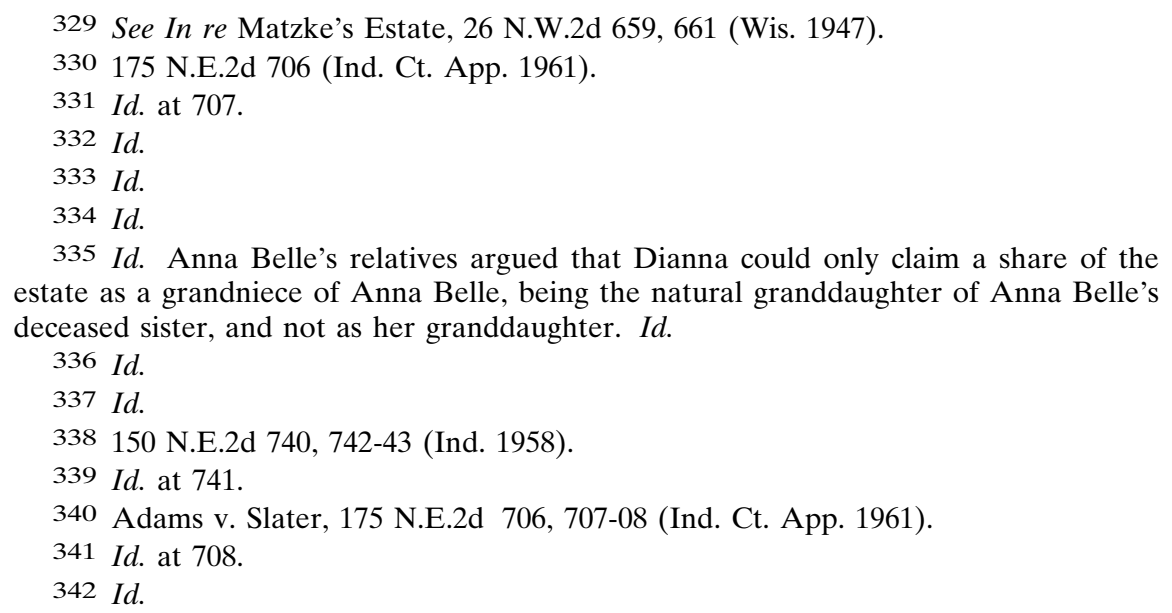


The court offered the following explanation for this curious interpretation of the revised probate code: When a married couple adopts an adult, particularly when the adoptee's natural parents are dead, "they might take pride in having grandchildren and knowing that the fruits of their own labors do not go unattended." 343 Consequently, the court declared that "it has no right to allow collateral relatives to disturb either the relationship of the adoptive parent to the adopted child or the relationship of the adoptive parent to the adopted child's natural child who, in both a legal and moral sense, should retain all the rights of a natural grandchild." 344 Therefore, it affirmed the lower court's holding that Dianna was entitled to claim Anna Belle's entire estate as her grandchild. ${ }^{345}$

In In re Estate of Brittin, ${ }^{346}$ an Illinois appellate court considered whether children of an adult adopted child who were alive at the time of the adoption should be considered to be grandchildren of the adoptive parents. When Stephen Brittin married Estelle, she had a child, William, who was three years old at the time of his mother's marriage. ${ }^{347}$ The couple had a daughter of their own, Mary Buckman. ${ }^{348}$ Shortly after Estelle died in 1975, Stephen adopted William, who was then 46 years old and the father of five children. ${ }^{349}$ William died in 1979, survived by his children and Stephen died intestate in 1993, survived by daughter, Mary. ${ }^{350}$ After Stephen's death, William's children claimed a share of his estate. ${ }^{351}$ However, Mary, who had been appointed as administrator of the estate, opposed the children's claim..$^{352}$

Mary acknowledged that William, as an adopted child, would have been entitled to one-half of Stephen's estate if he had survived. ${ }^{353}$ However, she argued that since William's children were alive at the time of his adoption, they could not be considered descendants of an "adopted child" as specified in the state's probate code. ${ }^{354}$ The lower court, however, ruled that William's children could take his share of the estate by representation. ${ }^{355}$ On appeal, the lower court's decision was upheld. ${ }^{356}$

343 Id. at 709.

344 Id. at $710-11$.

345 Id. at 711.

346664 N.E.2d 687, 689 (Ill. App. Ct. 1996).

347 Id. at 688.

348 Id.

349 Id.

$350 \mathrm{Id}$.

351 Id. at 689 .

352 Id. at $688-89$.

353 Id. at 689.

354 Id.

355 Id. at 688.

356 Id. at 691. 
The court reasoned that if the probate code treated an adopted child as a descendant of the adoptive parent, the children of the adopted child must also be descendants and occupied the status of grandchildren. ${ }^{357}$ Hence, it did not matter whether they were alive at the time of the adoption or were born afterwards. 358

In some cases, an adult adoption may have the effect of disinheriting members of the adoptee's biological family even though the adoption was not intended to sever the adoptee's relationship with his or her existing family. For example, in Kummer v. Donak, ${ }^{359}$ Justine Critzer died intestate in 2006 without a surviving spouse, children, parents or siblings and it appeared that her only heirs were distant cousins. ${ }^{360}$ However, three nieces and nephews, the children of Justine's sister, Mary Frances Kummer, subsequently claimed the estate as Justine's closest surviving relatives. ${ }^{361}$ The issue was further muddled by the discovery that Mary Frances had been adopted in 1981 at the age of 53 by her aunt by marriage, Arietta Kaleta. ${ }^{362}$ At that point, the administrator of Justine's estate petitioned the circuit court for a ruling on the effect the adoption would have on the inheritance rights of the Kummer children. ${ }^{363}$ The court concluded that the adoption of Mary Frances severed her right to inherit from Justine and severed the right of her children to inherit as well. ${ }^{364}$

On appeal, the Kummer children argued that their mother's adoption should not sever their right to inherit from their aunt. ${ }^{365}$ The appellate court pointed out that section 64.1-5.1 of the Virginia Code provided that a relationship of parent and child must be established in order for a person to take the share of another by representation. ${ }^{366}$ Furthermore, in order to inherit as the descendants of Justine's sister, the Kummer children had to show that Justine and Mary Frances were legally sisters for purposes of intestate succession. ${ }^{367}$ According to the court, "Applying the unambiguous language of Code $\S 64.1-5.1$, Mrs. [Mary Frances] Kummer became the child of her adopting parent and no longer was the child of her biological parents. Consequently, Critzer

357 Id.

$358 I d$.

359715 S.E.2d 7, 8 (Va. 2011).

$360 \mathrm{Id}$. at 8.

361 Id.

362 Id.

$363 I d$.

$364 I d$.

$365 I d$. at 9.

366 Id.

$367 I d$. 
and Mrs. Kummer, while biologically sisters, were not legally sisters for purposes of intestate succession under Code $\S 64.1-1 . " 368$

The court also declared that a provision of the state's adoption statute, section 63.2-1215, provided that an adopted child becomes the child of the adopting parent and is thereby placed on an equal footing with other members of her adoptive family. ${ }^{369}$ In the court's view, "[t]his provision divested Mrs. Kummer's biological parents of their legal rights with respect to Mrs. Kummer. Such divestiture extends to collateral relatives whose interest derives through the parents, which includes Crtizer." 370

In Estate of Mills, the Iowa Supreme Court engaged in similar reasoning to deny the biological parent of an adult adoptee the right to inherit her estate. ${ }^{371}$ Inez Mills, the daughter of Earl and Lydia Mills, went to live with her mother's half-brother, Gustav Possehl when she was 11 or 12 years old. ${ }^{372}$ Gustav adopted Inez when she was 25 years old. ${ }^{373}$ Gustav died in 1970 and Inez died intestate in $1983 .{ }^{374}$ Inez survived Earl, Lydia and her sister, Mae, but she was survived by her siblings, Dale, Pauline and Betty, as well as by Darwin, a son of Mae. ${ }^{375}$ Both Inez's biological relatives and Gustav's heirs claimed her estate. ${ }^{376}$ The lower court ruled in favor of Gustav's heirs, relying on a provision of the adoption statute that declared that "a lawful adoption extinguishes the right of intestate succession of a natural parent from and through the parent's natural born child who is adopted." 377 On appeal, Inez's relatives contended that this provision should not apply to singleparent adoptions. ${ }^{378}$ The appellate court acknowledged that the statute had once permitted inheritance through the biological parents of an adopted adult, but it observed that this provision had been repealed. ${ }^{379}$ Consequently, it affirmed the lower court's decision in favor of Gustav's heirs. ${ }^{380}$

To summarize, an adult adoptee can usually inherit from and through his or her adoptive parents. On the other hand, the right to

$368 I d$.

369 Id. at 10.

$370 \mathrm{Id}$.

371 In re Estate of Mills, 374 N.W.2d 675 (Iowa 1985).

372 Id. at 676.

373 Id.

$374 I d$.

375 Id.

376 Id.

377 Id. at 677.

378 Id.

379 Id.

380 Id. 
inherit from the adoptee's biological family may be lost, regardless of the expectations of the parties involved. This arguably makes little sense. Since an adult adoption does not involve a fresh start as it does in the case of children, it is questionable whether an adult adoptee should be allowed to inherit from ancestors or collateral members of the adoptive parent's family. Even if adult adoption is viewed as a mechanism for the post-mortem transfer of property from one adoptive party to the other, there is no reason to extend the right to inheritance to third parties. At the same time, since most adult adoptees retain close ties with their biological families, their right to inherit under a state's intestacy law should not be cut off by an adoption.

\section{Class Gifts in Wills and Trusts}

Part V was concerned with the right of adopted persons to inherit from their adoptive parents and other family members who die intestate. In such cases, when courts have to decide questions about an adoptee's right to inherit, they must determine legislative intent as embodied in adoption laws and statutes of descent and distribution. In contrast, when a will or trust is involved, a court must ascertain the settlor's or testator's intent to determine whether an adult adoptee should be included within a designated class of beneficiaries such as children, issue, descendants, heirs or next of kin. ${ }^{381}$ This process involves an examination of "the words of the instrument and, if necessary, the scheme of distribution, the circumstances surrounding the execution of the will [or trust] and other facts bearing on the question [of intent]." ${ }^{82}$ Of course, determining a testator's intent is not difficult when it is clearly expressed. However, when the language of a will or trust is ambiguous, or silent on this issue, the court must rely on statutory directives, canons of construction or other interpretive tools.

381 See Estate of Pittman v. Tuffree, 163 Cal. Rptr. 527, 529 (Ct. App. 1980); In re Tr. Created by Belgard, 829 P.2d 457, 459 (Colo. App. 1991); Munie v. Gruenewald, 124 N.E. 605, 606 (Ill. 1919); Paloutzian v. Taggart, 931 N.E.2d 921, 925 (Ind. Ct. App. 2010); Elliott v. Hiddleson, 303 N.W.2d 140, 142 (Iowa 1981); Lockwood v. Adamson, 566 N.E.2d 96, 98 (Mass. 1991); In re Trs. of Harrington, 250 N.W.2d 163, 165 (Minn. 1977); Commerce Tr. Co. v. Weed, 318 S.W.2d 289, 294 (Mo. 1958); In re Estate of Sykes, 383 A.2d 920, 921 (Pa. 1978); In re Hamilton's Estate, 312 A.2d 373, 374 (Pa. 1973); Security Nat'l Bank \& Tr. Co. v. William, 153 S.E.2d 114, 118 (W. Va. 1967).

382 See In re Sykes, 383 A.2d at 921; see also Mooney v. Tolles, 149 A. 515, 518 (Conn. 1930); Elliott v. Hiddleson, 303 N.W.2d 140, 142 (Iowa 1981); In re Estate of Wolf, 236 A.2d 166, 169 (N.J. Super. Ct. App. Div. 1967); In re Estate of Kauffman, 506 A.2d 951, 952-53 (Pa. Super. Ct. 1986). 


\section{A. Statutes, Presumptions and Rules of Construction}

In a few states, statutes identify the inheritance rights of adult adoptees in general terms only. For example, Minnesota's adult adoption statute declares that the adoption decree establishes a parent-child relationship between the parties, "including the right to inherit." 383 The West Virginia adoption statute also makes a general reference to the right to inherit. ${ }^{384}$ However, the Texas adoption statute is more specific, providing that the adopted adult "is entitled to inherit from and through the adopted adult's adoptive parents as though the adopted adult were the biological child of the adoptive parents." 385 In addition, the statute states that "[ $\mathrm{t}]$ he adopted adult retains the right to inherit from the adult's biological parents," but denies the biological parents the right to inherit from or through the adopted adult. ${ }^{386}$ Finally, a Colorado adoption statute permits an adult to enter into an agreement with another adult to determine inheritance rights. ${ }^{387}$ Although these statutes primarily apply to intestacy, courts rely on them in other cases as well. In addition, many other statutes declare that adoptees have the same rights and privileges as natural children without mentioning inheritance specifically. ${ }^{388}$

In the absence of express statutory guidance, courts often rely on presumptions to decide whether a testator intended an adoptee to take a share of a class gift. For example, in the past, many states recognized a "stranger to the adoption" rule that presumed that relatives of the adoptive parent, who were not parties to the adoption, would not want an adoptee to take a share of their estate as beneficiaries of a class gift under a will or a trust. ${ }^{389}$ This presumption could only be overcome by

\footnotetext{
383 See Minn. Stat. § 259.241(c) (2016).

384 See W. VA. CODE $\$ 48-22-801$ (2016).

385 See Tex. Fam. Code Ann. § 162.507(b) (2015).

386 See Id. $\$ 162.507$ (c).

387 See Colo. Rev. Stat. § 14-1-101(2) (2016).

388 See, e.g., Ariz. Rev. Stat. Ann. § 14-8101(B) (2016); Cal. Fam. Code $\$ 9305$ (West 2016); Colo. Rev. Stat. § 19-5-211 (2016); Del. Code Ann. tit. 13, § 954 (2016); Ga. Code Ann. § 19-8-21(a) (2016); Ky. Rev. Stat. Ann. $\$ 405.390$ (West 2016); S.C. Code Ann. § 63-9-1120 (2016); Vt. Stat. Ann. tit. 15A, § 5-102 (2016);Wis. Stat. $\S 882.04$ (2016).

389 See Abramovic v. Brunken, 94 Cal. Rptr. 303, 305 (Ct. App. 1971); Conn.Bank \& Tr. Co. v. Bovey, 292 A.2d 899, 902-03 (Conn. 1972); Mooney v. Tolles, 149 A. 515 (Ct. 1930); Comer v. Comer, 23 S.E.2d 420, 425 (Ga. 1942); Paloutzian v. Taggart, 931 N.E.2d 921, 923 (Ind. Ct. App. 2010); Lutz v. Fortune, 758 N.E.2d 77, 81-83 (Ind. Ct. App. 2001); Mesecher v. Leir, 43 N.W.2d 149, 151-52 (Iowa 1950); Savells v. Brown's Guardian, 218 S.W. 462, 462-63 (Ky. 1920); Fiduciary Tr. Co. v. Silsbee, 187 A.2d 396, 400 (Me. 1963); In re Tr. of Vander Poel, 933 A.2d 628, 638 (N.J. Super. Ct. App. Div. 2007); In re Leask, 90 N.E. 652, 654 (N.Y. 1910); N.Y. Life Ins. \& Trust Co. v. Viele, 55 N.E. 311, 314-15 (N.Y. 1899); 3d Nat'l Bank \& Tr. Co. v. Davidson, 105 N.E.2d 573, 579 (Ohio 1952); Cent. Tr.
} 
language in the instrument that manifested a clear intent to include adoptees in the class gift. The stranger to the adoption principle was based on a number of assumptions. First of all, it assumed that members of the adoptive family, other than the adoptive parents, would prefer to keep their property within the family bloodline. ${ }^{390}$ Second, the adoptive parent should not be able to impose kinship status on unwilling family members who were not parties to the adoption. ${ }^{391}$ Finally, an adoptive parent should not be able to thwart a testator's distributive scheme by adopting another person without his or her knowledge or consent. ${ }^{392}$

In re Woodcock ${ }^{393}$ provides a good illustration of how this presumption operated in the past. In 1890, Ann Johnson executed a will that left the balance of her estate to her daughter, Mary. ${ }^{394}$ If Mary died without children, the property was to go in equal shares to three of Ann's other children, Arabella, Horatio and Charles. ${ }^{395}$ Finally, if any of the three children were to die before Mary, his or her children would divide their parent's share. ${ }^{396}$ Amy died in 1891 and Mary died in 1906, apparently without surviving children. ${ }^{397}$ Meanwhile, Horatio died in 1896. ${ }^{398}$ He did not have any natural children, but had adopted a child, Ella, in 1882.399 At Mary's death, Ella claimed Horatio's share of the estate, arguing that she was his "child" for purposes of taking under the provisions of Ann's will. ${ }^{400}$ However, the probate court rejected Ella's claim. ${ }^{401}$

On appeal, the Maine Supreme Judicial Court acknowledged that an adopted child can take under the will of an adoptive parent who devises property to a child or children since "he is under obligation in

Co. v. Hart, 80 N.E.2d 920, 925 (Ohio Ct. App. 1948); In re Hayes' Estate, 86 P.2d 424, 435-36 (Or. 1939); In re Ray Ellison Grandchildren Tr., 261 S.W.3d 111, 122 (Tex. App. 2008); In re Harrington's Estate, 85 P.2d 630, 634-35 (Utah 1938).

390 See Nunnally v. Tr. Co. Bank, 261 S.E.2d 621, 624 (Ga. 1979); Comer, 23 S.E.2d at 425; Fiduciary Tr. Co., 187 A.2d at 400; In re Thompson, 250 A.2d 393, 396 (N.J. 1969); N.Y. Life Ins. \& Trust Co,. 55 N.E. at 314; In re Cave's Estate, 192 A. 460, 461 (Pa. 1937).

391 See In re Estate of Uihlein, 68 N.W.2d 816, 820 (Wis. 1955).

392 See In re Estate of Comly, 218 A.2d 175, 178 (Gloucester Cty. Ct. Prob. Div. 1966).

39368 A. 821 (Me. 1907).

394 Id. at 821.

$395 I d$.

$396 I d$.

397 Id.

398 Id.

399 Id.

400 Id. at 821-22.

401 Id. at 822 . 
morals, if not in law, to make provision for such child." ${ }^{402}$ However, the court concluded that result should not apply to a will made by someone else. ${ }^{403}$ According to the court:

When in a will provision is made for a "child or children" of some other person than the testator, an adopted child is not included, unless other language in the will makes it clear that he was intended to be included, which is not the case here. In making a devise over from his own children to their "child or children," there is a presumption that the testator intended "child or children" of his own blood, and did not intend his estate to go to a stranger to his blood. ${ }^{404}$

The court went on to observe that, although Ella was a child of Horatio by virtue of the adoption, she was not the grandchild of Horatio's mother, the testator, who "was under no sort of obligation, moral or family, to make any provision for her." 405 Finding no evidence in the will of a contrary intent, the court concluded that Ann intended Horatio's share "to go out of the blood" to an adopted child. ${ }^{406}$ Therefore, it affirmed the lower court's ruling that Ella was not entitled to take a share of the estate. ${ }^{407}$

Nowadays, the stranger to the adoption rule is no longer followed in most states. ${ }^{408}$ Thus, while a testator is free to exclude adoptees, he or she must now do so expressly. ${ }^{409}$ The principal reason for this turnaround, discussed earlier, is the emergence of a public policy that dic-

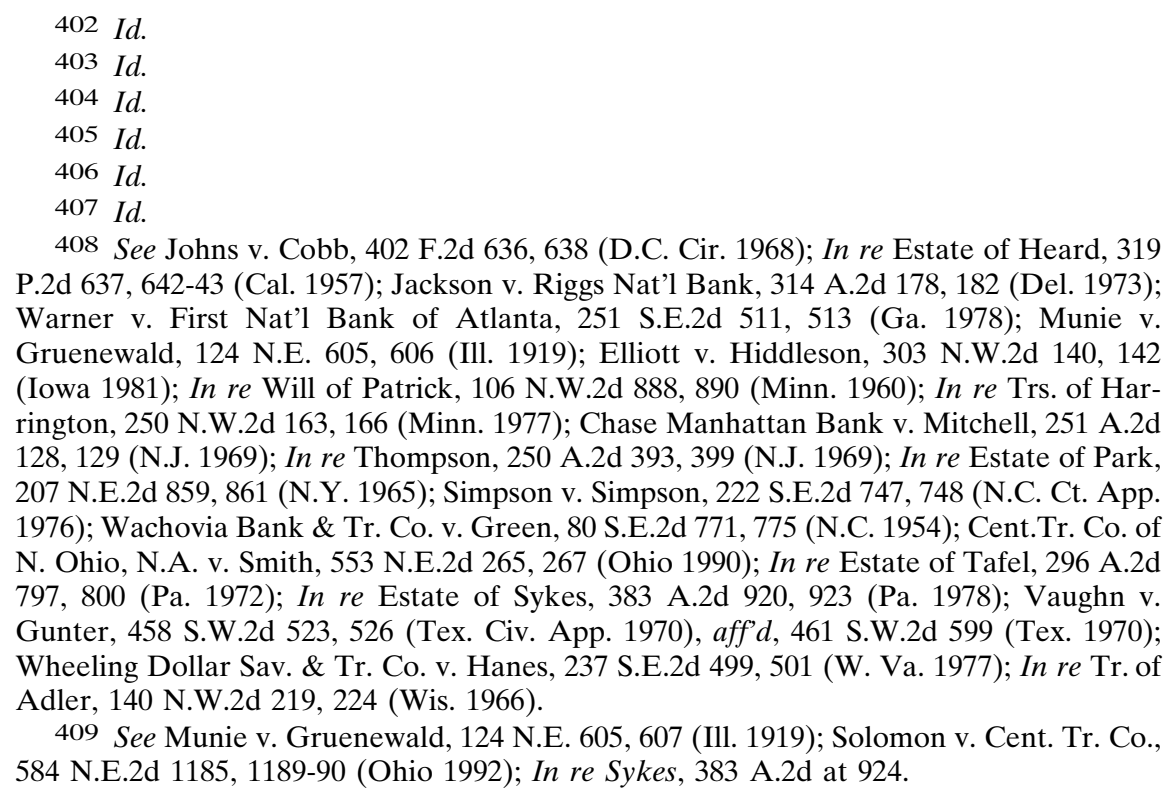


tates that an adopted child should sever all connection with his or her biological family and instead become fully integrated into the adoptive family. ${ }^{410}$

The California Supreme Court's decision in In re Estate of Heard was one of the first to discard the stranger to the adoption rule and embrace a more inclusionary approach. ${ }^{411}$ In that case, Emma Heard, a widow, executed a will in 1935 and died four years later, leaving a brother and a son, John. ${ }^{412}$ In her will, Emma created a trust with John as the principal income beneficiary. ${ }^{413}$ The trust also provided that at John's death, his income interest would be transferred to "his lawful issue, if any." 414 At the death of the last income beneficiary, the trust would terminate and the trust property would be delivered to the heirs of John's issue if any were living at that time. ${ }^{415} \mathrm{John}$ died without issue in 1955, but he and his wife adopted a child, John III, in 1950.416 Since some of the other income beneficiaries were still alive at the time of John's death, the issue before the court was whether John III would succeed to his income interest as John's lawful issue. ${ }^{417}$

The court began by observing that

The over-all purpose [of the adoption laws] evidently was to create a new legal relationship of parent and child which normally would be coupled with the natural relation of parent and child springing from the fact that that is the relationship in which they actually live; and to make the new legal relationship legally the same as the old legal relationship of parent and child which normally is coupled both with the genetic and factual relation of parent and child. ${ }^{418}$

The court went on to declare that since the status of an adopted child was the same as a biological offspring under state law, it must assume, unless the testator expressed an intent to the contrary, that she intended the provisions of her will to be compatible with this policy. ${ }^{419}$ Accordingly, the court concluded that "we do not find therein any indication

410 In re Heard, 319 P.2d at 641; Com. Tr. Co. v. Weed, 318 S.W.2d 289, 298 (Mo. 1958); see also In re Estate of Best, 485 N.E.2d 1010, 1012 (N.Y. 1985).

411 See In re Heard, 319 P.2d at 638.

412 Id.

$413 I d$.

$414 I d$.

$415 I d$. at 639 .

416 Id.

417 Id. at $639-40$.

418 Id. at 641.

419 Id. at 642 . 
that an adopted child was to be excluded in view of the public policy to treat adopted children the same as blood children." 420

\section{B. Adopted Persons as "Children," "Descendants," "Issue" and "Heirs" in Class Gifts}

Having concluded that most jurisdictions have adopted a presumption, at least where minor adoptees are concerned, that settlors and testators usually intend to include adoptees as beneficiaries in class gifts, it is now necessary to consider which, if any, words or phrases are sufficient to rebut the presumption and thereby exclude adoptees. These include class gifts to (1) children, (2) descendants or issue; and (3) heirs, next of kin or heirs of the body. The right of minor adoptees will be discussed first before considering adult adoptees.

\section{Children}

The term "children" seems to be more expansive than any of the other words or phrases listed above and adopted children would seem to fall within this category if not otherwise limited in some way. ${ }^{421} \mathrm{Be}-$ cause adopted children are considered to be children of their adoptive parents, in the absence of any limiting language, a class gift by the adoptive parent to his or her "children" will almost always be deemed to include adopted children. ${ }^{422}$ Furthermore, adoption statutes in many jurisdictions declare that adopted children can take as beneficiaries of class gifts made to the "children" of their adopted parents. ${ }^{423}$ In other states, court decisions have reached the same result without a statutory mandate. ${ }^{424}$

In re Estate of Darling ${ }^{425}$ provides a good illustration of the modern approach. In that case, a testamentary trust established by Frances Dar-

420 Id. at 643.

421 But see Wilson v. Johnson, 389 S.W.2d 634, 636 (Ky. 1965) (holding that the use of the term "children" does not include adoptees, although terms like "heirs" and "heirs at law" do).

422 See In re Appeal of Wildman, 151 A. 265, 266 (Conn. 1930).

423 See In re Estate of Darling, 365 N.W.2d 821, 823 (Neb. 1985); In re Estate of Tafel, 296 A.2d 797, 800 (Pa. 1972).

424 See Mooney v. Tolles, 149 A. 515, 519 (Conn. 1930); Munie v. Gruenewald, 124 N.E. 605, 607 (Ill. 1919); Meek v. Ames, 280 P.2d 957, 962 (Kan. 1955); In re Estate of DeRoy, 392 A.2d 1355, 1357-58 (Pa. 1978). However, this approach is not universal, and in some of the earlier cases, the courts have not allowed adopted children to qualify unless the settlor or testator has expressly included them as children. See Conn. Bank \& Tr. Co. v. Bovey, 292 A.2d 899, 902 (Conn. 1972); In re Leask, 90 N.E. 652, 654 (N.Y. 1910); Cent. Tr. Co. v. Hart, 80 N.E.2d 920, 927(Ohio Ct. App. 1948); Cochran v. Cochran, 95 S.W. 731, 732 (Tex. Civ. App. 1906); Decker v. Elliott, 425 S.W.2d 880, 883 (Tex. Civ. App. 1968); Murphy v. Slaton, 273 S.W.2d 588, 597 (Tex. 1954).

425365 N.W.2d 821 (Neb. 1985). 
ling provided that after the death of her son, David Darling, the trust property would be divided among "the children of said David H. Darling who survive him." 426 Frances died in 1967.427 David was married four times and had one child by his first marriage, another two by his second marriage and a fourth child by his third marriage. In 1977, David adopted the four children of his fourth wife. ${ }^{428}$ David died in 1982 and his four adopted children claimed a share of the trust, while David's biological children disputed the adopted children's claim. ${ }^{429}$

Relying on In re Clarke's Estate, ${ }^{430}$ the biological children argued that there was a presumption that children adopted after the death of a testator were not meant to be included in any bequest to "children." 431 However, the Nebraska Supreme Court held that a subsequently-enacted state statute overruled the Clarke case and provided that adopted children should share in the trust in the same manner as biological children even when they had been adopted after the testator's death. ${ }^{432}$

\section{Descendants, Lineal Descendants or Issue}

The terms "descendants," "lineal descendants" or "issue" have the same meaning in legal parlance, namely a person's lineal descendants by blood. 433 Many of the older cases excluded adopted children from a beneficiary class when the beneficiaries were described as issue or descendants of the adoptive parents, either because they adhered to the stranger to the adoption rule ${ }^{434}$ or because they defined these terms according to their traditional meaning. ${ }^{435}$ However, nowadays most courts tend to either apply the modern presumption in favor of including adoptees ${ }^{436}$ or to rely on expressions of state policy in adoption stat-

\footnotetext{
426 Id. at 823

427 Id.

$428 I d$.

$429 I d$.

430 See In re Clarke's Estate, 251 N.W. 279 (Neb. 1933).

431 See In re Estate of Darling, 365 N.W.2d 821, 823 (Neb. 1985).

432 Id. at 824.

433 See Conn. Bank \& Tr. Co. v. Hills, 254 A.2d 453, 455 (Conn. 1969); In re Estate of Wehrhane, 128 A.2d 681, 682 (N.J. 1957).

434 See Conn. Bank \& Tr. Co. v. Bovey, 292 A.2d 899, 902-03 (Conn. 1972); Fiduciary Tr. Co. v. Silsbee, 187 A.2d 396, 400 (Me. 1963); In re Wehrhane, 128 A.2d at 683; Mealy v. First Nat'l Bank \& Tr. Co., 445 P.2d 795, 797 (Okla. 1968).

435 See Trowbridge v. Trowbridge, 17 A.2d 517, 519 (Conn. 1941); Ford v. Newman, 381 N.E.2d 292, 397 (Ill. App. Ct. 1978), aff'd, 396 N.E.2d 539 (Ill. 1979); Cont'l Ill. Nat'l Bank \& Tr. Co. v. Clancy, 163 N.E.2d 523, 526 (Ill. 1959); In re Estate of Graham, 150 N.W.2d 816, 817 (Mich. 1967); In re Wehrhane, 128 A.2d at 682-83; N.Y. Life Ins. \& Tr. Co. v. Viele, 55 N.E. 311, 314 (N.Y. 1899); Cent. Tr. Co. v. Hart, 80 N.E.2d 920, 925 (Ohio Ct. App. 1948).

436 See In re Estate of Sykes, 383 A.2d 920, 923 (Pa. 1978).
} 
utes and elsewhere that consider adoptees to be full-fledged members of their adoptive families. ${ }^{437}$

The Thompson case provides a good example of this latter approach. ${ }^{438}$ In that case, the testator's will created a trust under which his widow and four children received income from the trust, with a remainder to each child's issue. ${ }^{439}$ After the testator's death, one of his children, Geraldine, and her husband adopted Roger Boone. When Geraldine died in 1949, the trustees decided to pay her share of the income from the trust to her biological child, Peter, and to pay nothing to Roger. ${ }^{440}$ When the testator's widow died in 1967, the trustees sought a ruling on whether Roger was entitled to receive a portion of the trust corpus. ${ }^{441}$ The trial court concluded that Roger was not Geraldine's issue insofar as the trust was concerned. ${ }^{442}$ On appeal, the New Jersey Supreme Court, relying on the reasoning of In re Estate of Coe, ${ }^{443}$ held in favor of Roger. ${ }^{444}$ After reviewing the adoption statute and various decisions from the courts of other states, the court concluded that, given the trend toward recognizing the rights of adopted children, the testator would not have used the term "issue" if he desired to exclude adopted children from the class of trust beneficiaries. ${ }^{445}$

\section{Heirs and Next of Kin}

At common law, the term "heir" referred to one who inherited a decedent's real property, while the term "nest of kin" referred to the distributes of the decedent's personal property under the civil law's "degrees of kinship" approach. However, these terms are now used more or less interchangeably to refer to those who may inherit a share of a decedent's estate under the laws of descent and distribution. In contrast, the term "heirs of the body" is more restrictive and refers to "off-

437 See Johns v. Cobb, 402 F.2d 636, 638 (D.C. Cir. 1968); Mooney v. Tolles, 149 A. 515, 518 (Conn. 1930); In re Thompson, 250 A.2d 393, 399 (N.J. 1969); In re Estate of Park, 207 N.E.2d 859, 861 (N.Y. 1965); Dollar Sav. \& Tr. Co. v. Musto, 181 N.E.2d 734, 735 (Ohio Ct. App. 1961); In re Olney, 63 A. 956, 957 (R.I. 1906); Hartwell v. Tefft, 35 A. 882, 883 (R.I. 1899); In re Tr. of Adler, 140 N.W.2d 219, 225-26 (Wis. 1966).

438 In re Thompson, 250 A.2d at 393.

439 Id. at 394.

$440 \mathrm{Id}$.

441 Id.

442 Id. at 393.

443201 A.2d 571 (N.J. 1964).

444 See In re Thompson, 250 A.2d 393, 395 (N.J. 1969).

445 Id. However, adult adoptees are not necessarily given the same treatment, resulting in part from the "stranger to the adoption" rule. See In re Tr. of Vander Poel, 933 A.2d 628, 636-38 (N.J. Super. Ct. App. Div. 2007). 
spring, progeny, natural children, physically born and begotten by the person named as a parent." 446

In the past, when the beneficiary class is defined as "heirs" or "next of kin," adoptees were often excluded under the stranger to the adoption rule. ${ }^{447}$ However, minor adoptees are now typically included when courts apply the modern presumption that favors adoptees. 448

\section{Biological Parents and Relatives}

The modern view of adoption has generally precluded minor adoptees from inheriting a share of the estates of biological parents or other biological relatives who died intestate. Of course, biological parents and other blood relatives are free to make bequests in their wills to those who have been adopted out of the family. In some states, adoption statutes address the issue as they do in cases of intestacy. However, in the absence of such statutory guidance or a clear directive in the will or trust, the majority of courts allow adopted children to qualify as beneficiaries under wills and trusts of their biological parents and relatives, ${ }^{449}$ although a few have excluded them from doing so. ${ }^{450}$

\section{Cases Involving Adult Adoptees}

\section{Class Gifts from Adoptive Relatives}

Although the majority of courts have upheld the right of minor adoptees to share in class gifts established in wills and trusts of members of their adoptive families, they are not in agreement as to whether the right to inherit should also extend to adult adoptees. ${ }^{451}$ A number of

\footnotetext{
446 See Comer v. Comer, 23 S.E.2d 420, 424 (Ga. 1942); see also Delaney v. First Nat'l Bank, 386 P.2d 711, 716 (N.M. 1963).

447 See Cook v. Underwood, 228 N.W. 629, 631 (Iowa 1930).

448 See Elliott v. Hiddleson, 303 N.W.2d 140, 142 (Iowa 1981); U.S. Tr. Co. v. Hoyt, 135 N.Y.S. 849, 856 (App. Div. 1912).

449 See Conn. Bank \& Tr. Co. v. Coffin, 563 A.2d 1323, 1331 (Conn. 1989); Monroney v. Mercantile-Safe Deposit \& Tr. Co., 435 A.2d 788, 796 (Md. 1981); Lockwood v. Adamson, 566 N.E.2d 96, 101 (Mass. 1991); In re Estate of Wolf, 236 A.2d 166, 170 (N.J. Super. Ct. App. Div.1967); In re Estate of Lippincott, 532 N.Y.S.2d 1021, 1024 (Sur. Ct. Erie Cty. 1988); In re Estate of Zastrow, 166 N.W.2d 251, 254 (Wis. 1969).

450 See In re Estate of Russell, 95 Cal. Rptr. 88, 95 (Ct. App. 1971); In re Estate of Best, 485 N.E.2d 1010, 1012-13 (N.Y. 1985).

451 See Estate of Pittman v. Tuffree, 163 Cal. Rptr. 527, 531 (Ct. App. 1980); In re Stanford, 315 P.2d 681, 708-09 (Cal. 1957); Abramovic v. Brunken, 94 Cal. Rptr. 303, 305 (Ct. App. 1971); In re Tr. Created by Belgard, 829 P.2d 457, 460 (Colo. App. 1991); Otto v. Gore, 45 A.3d 120, 136-37 (Del. 2012); First Nat'l Bank v. Mackey, 338 N.W.2d 361, 365 (Iowa 1983); Wilson v. Johnson, 389 S.W.2d 634, 634 (Ky. 1965); Wyeth v. Stone, 11 N.E. 729, 732 (Mass. 1887); First Nat'l Bank v. Sullivan, 394 S.W.2d 273, 283 (Mo. 1965); Jenkins v. Jenkins, 14 A. 557, 558 (N.H. 1888); In re Estate of Nicol, 377 A.2d 1201, 1208 (N.J. Super. Ct., App. Div. 1977); In re Estate of Comly, 218 A.2d 175, 178 (Gloucester
} 
courts have treated adult adoptees the same as minors as far as class gifts are concerned. ${ }^{452}$ However, the majority of courts have not been willing to allow adult adoptees to qualify for class gifts, particularly if the adoption occurs after the settlor or testator's death. ${ }^{453}$

Courts that treat adults and minors the same often base their decisions on either statutory directives ${ }^{454}$ or evidentiary presumptions. ${ }^{455}$ For example, in In re Estate of Fortney, the court held that an adult adoptee was a "child" and, therefore, fell within a statute that provided that "an adopted child has the same rights of person and property as a natural child of the person adopting would have." 456

A Delaware court in Chichester v. Wilmington Trust Co. also interpreted a state statute to allow two adult adoptees to take a share of a class gift as the "issue" of their adoptive parents. ${ }^{457}$ This case involved two trusts created by Philip Laird and a will executed by his wife, Lydia Laird. ${ }^{458}$ Each instrument named the issue of Lydia's mother, Eliza Chichester, as beneficiaries. ${ }^{459}$ One of Eliza's sons, Robert, adopted two of his wife's children by a prior marriage when they were adults. After Lydia's death, litigation ensued between the adoptees and Eliza's biological issue. ${ }^{460}$ The lower court ruled in favor of the adult adoptees. ${ }^{461}$ The appellate court observed that the state adoption statute provided that adopted adults were to be treated as the lawful and natural offspring of their adoptive parents. 462 The court pointed out that the adult adoptees could have taken a share of the Laird's property

Cty. Ct. Prob. Div. 1966); In re Estate of Griswold, 354 A.2d 717, 733 (Morris Cty. Ct. Prob. Div. 1976); In re Estate of Goal, 551 A.2d 309, 313 (Pa. Super. Ct. 1988); In re Estate of Ketcham, 495 A.2d 594, 597 (Pa. Super. Ct. 1985); In re Estate of Kauffman, 506 A.2d 951, 956 (Pa. Super. Ct. 1986); Fleet Nat'l Bank v. Hunt, 944 A.2d 846, 853 (R.I. 2008).

452 See Chichester v. Wilmington Tr. Co., 377 A.2d 11, 13 (Del. 1977); In re Estate of Fortney, 611 P.2d 599, 604 (Kan. Ct. App. 1980); Evans v. McCoy, 436 A.2d 436, 449 (Md. 1981); In re Trs of Harrington, 250 N.W.2d 163, 166 (Minn. 1977); Brock v. Dorman, 98 S.W.2d 672, 676 (Mo. 1936); Satterfield v. Bonyhady, 446 N.W.2d 214, 216 (Neb. 1989); Delaney v. First Nat'l Bank, 386 P.2d 711, 716 (N.M. 1963); In re Chemical Bank, 395 N.Y.S.2d 917, 921 (Sup. Ct. 1977).

453 See In re Nicol, 377 A.2d at 1208; In re Comly, 218 A.2d at 178; In re Griswold, 354 A.2d at 733; In re Goal, 551 A.2d at 313.

454 See Chichester, 377 A.2d at 13; In re Fortney, 611 P.2d at 604; Satterfield, 446 N.W.2d at 216.

455 See Evans, 436 A.2d at 439-40; In re Harrington, 250 N.W.2d at 166.

456611 P.2d 599, 604 (Kan. Ct. App. 1980).

457377 A.2d 11, 14 (Del. 1977).

$458 \mathrm{Id}$. at 12.

459 Id.

$460 I d$.

461 Id. at 12.

462 Id. at 13 (citing Del. Code. Ann. tit. 13, § 954 (2016)). 
as issue of Robert if they had been adopted by him as minors. ${ }^{463}$ Consequently, it concluded that it should construe the statute "to require the same result in the case of a child adopted as an adult." 464

Another approach is to apply the presumption in favor of inclusion that applies to minor adoptees in many states. ${ }^{465}$ For example, in the Trusts of Harrington case, Charles Harrington created several testamentary trusts that provided income for the children of his daughter, Laura Belle Hudson, "the issue of her body," with a gift over to certain charities in the absence of such issue. ${ }^{466}$ The settlor died in 1928. ${ }^{467}$ Prior to his death, Katherine and Edwin Dodge came to live with Laura Belle and her husband as teenagers and were formally adopted by them in 1933 as adults. ${ }^{468}$ After Laura Belle's death, Katherine and the heirs of Edwin claimed to be beneficiaries under the trusts. ${ }^{469}$ The charitable remaindermen contested this claim, arguing that Harrington did not intend for adopted children of Laura Belle to benefit. ${ }^{470}$ The lower court ruled that the adopted children were not Laura Belle's issue and they appealed. ${ }^{471}$

The appellate court observed that the state's adoption statutes, beginning in 1905, had provided that an adopted child "shall inherit from his adopting parents or their relatives the same as though he were the legitimate child of such parents." ${ }^{472}$ The court also pointed out that an earlier case, In re Holden's Trust, ${ }^{473}$ had held that the word "issue" in a testamentary provision should be construed to include adopted children by virtue of the state's adoption statutes "where a contrary intention is not shown." Applying this presumption, the court concluded that the trusts did not indicate that the testator intended to include only the biological children of Laura Belle. ${ }^{474}$

Those courts that have upheld the exclusion of adult adoptees have also offered a number of rationales to support their position. One argument is that adult adoptions are not the same as the adoption of minors and, therefore, adult adoptees are not entitled to the same preferential

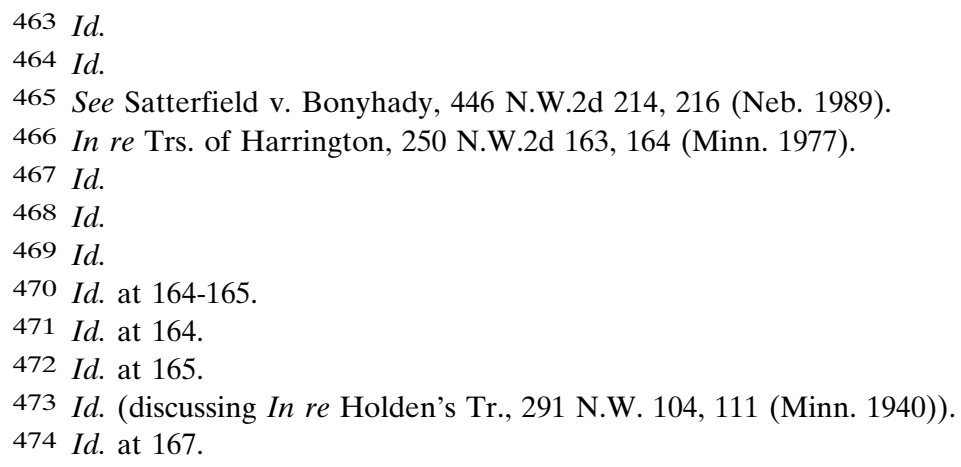


treatment as minors. ${ }^{475}$ For example, a New Jersey appellate court took this approach in In re Estate of Nicol. ${ }^{476}$ In 1939, Minnie Nicol died, leaving her residuary estate in a testamentary trust for the benefit of her sisters, as well as her children and grandchildren. ${ }^{477}$ In 1952, one of her four children, Alexander Nicol, adopted the four adult children by a prior marriage of his wife, Frances. ${ }^{478}$ Alexander died in 1961. ${ }^{479}$ When it became time to distribute the trust corpus, Alexander's adopted children claimed a share on the theory that they were "issue or lineal descendants" of Minnie. ${ }^{480}$ The lower court upheld the adoptees' claim and the other remaindermen appealed. ${ }^{481}$

Reversing the lower court's judgment, the appellate court held that Minnie did not intend to leave a share of the trust property to Alexander's adopted children. ${ }^{482}$ The court began by acknowledging that prior decisions had rejected the stranger to the adoption rule by reasoning that members of the adoptive family would not differentiate between a natural child and one who had been adopted, but rather "the relationships established by the parent would be accepted without discrimination on a biological basis." 483 In contrast, the court declared that it was unlikely "that an adopted adult would be embraced in the bosom of family members other than the adopting parent as would an adopted child." 484 Accordingly, the court concluded that Minnie would not have desired that her son's adult adoptees share in her estate. ${ }^{485}$

Some courts have denied the right of an adult adoptee to qualify as a class member unless a parent-child relationship existed prior to the adoption. ${ }^{486}$ This approach is illustrated by In re Estate of Goal. ${ }^{487}$ In that case, the will of Albert Goal provided that his two children, Helen

475 See In re of Estate of Nicol, 377 A.2d 1201, 1206-08 (N.J. Super. Ct. App. Div. 1977); In re Estate of Comly, 218 A.2d 175, 178 (Gloucester Cty. Ct. Prob. Div. 1966); In re Estate of Griswold, 354 A.2d 717, 726-27 (Morris Cty. Ct. Prob. Div. 1976); In re Hagar's Estate, 126 A. 507, 509 (Vt. 1924).

476 In re Nicol, 377 A.2d at 1206-08.

477 Id. at $1202-03$.

478 Id. at 1203.

$479 I d$.

480 Id. at 1204.

481 Id. at 1203 .

482 Id. at 1208.

483 Id. at 1204-06 (citing In re Coe, 201 A.2d 571 (N.J. 1964) and In re Thompson, 250 A.2d 393 (N.J. 1969)).

484 Id. at $1207-08$.

485 Id. at 1208.

486 See First Nat'l Bank of Dubuque v. Mackey, 338 N.W.2d 361, 365 (Iowa 1983); Wilson v. Johnson, 389 S.W.2d 634, 634 (Ky. 1965); In re Estate of Kauffman, 506 A.2d 951, 955 (Pa. Super. Ct. 1986); In re Estate of Goal, 551 A.2d 309, 311 (Pa. Super. Ct. 1988).

487551 A.2d at 311 (Pa. Super Ct. 1988). 
and Robert, should receive income from a testamentary trust for their lives. ${ }^{488}$ After the death of Helen and Robert, the trust income was to be distributed to their issue. ${ }^{489}$ Robert died in 1987 , survived by three natural daughters and a son who had been adopted when he was 41 years old. ${ }^{490}$ The adoptee argued that he was Robert's issue and, therefore, should receive a share of the trust income in accordance with the terms of Albert's will. 491 On appeal, a Pennsylvania court agreed that the state's adoption statutes mandated that adopted children should have the same rights as natural children. ${ }^{492}$ This policy was reflected in the presumption that references in a will or trust to "children," "issue" and the like would include adoptees as well as biological kindred.493 However, the court also declared that it was contrary to public policy to allow a beneficiary to frustrate a testator's intent by adopting an adult after his death. ${ }^{494}$

In the court's view, the best way to achieve a balance between these two policies was to limit the inclusionary presumption in adult adoption cases to situations where a "parent-child" relationship existed between the adoptive parent and the adult adoptee. Quoting from In re Estate of Kauffman, ${ }^{495}$ the court declared that

When an adoption is effectuated because of a parent-child relationship, then it is logical for the court to presume that when no contrary intent is shown, the testator would have wanted the adopted child included in a legacy or bequest to "children." In such a case, the adopted person fits the meaning commonly associated with the word "child," and is no different from natural siblings except for the biological ties. However, when no parent-child relationship exists, and the adoption is effectuated to secure an inheritance, it would not be logical to presume that the testator would have intended the adoptee to be included. Accordingly, the court in construing the language of the will will exclude such adult adoptees who had no parentchild relationship from sharing a legacy or bequest to "children."496

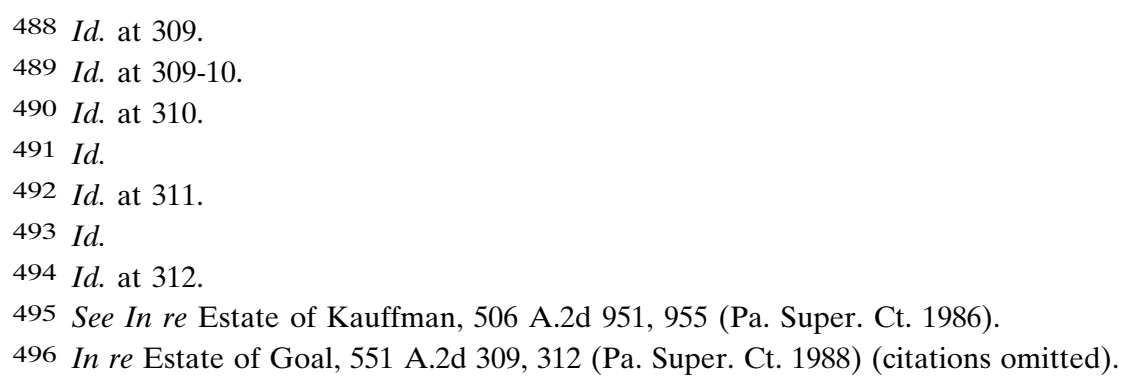


Applying this reasoning to the facts of the case, the court in In re Estate of Goal observed that there was no evidence that Robert and the adoptee had developed a parent-child relationship while the adoptee was still a minor. ${ }^{497}$ Therefore, the court held that the adult adoptee could not be treated as one of Robert's issue. ${ }^{498}$

Finally, some courts are inclined to exclude adult adoptees from sharing in class gifts if they suspect that the adoption was based on improper motives. ${ }^{499}$ Otto $v$. Gore provides an interesting example of this approach. ${ }^{500}$ In May and again in October of 1972, Wilbert (Bill) Gore, the inventor of GORE-TEX ${ }^{\circledR}$ fabric, and his wife, Genevieve (Vieve), executed Trust agreements for the benefit of their grandchildren, each listing a considerable amount of company stock on Schedule A..$^{501}$ The two trusts purported to transfer the same property, but utilized different distribution formulas. ${ }^{502}$ Susan Gore, one of Bill and Vieve's five children, married Jan Otto and had three children, Nathan, Jan and Joel. ${ }^{503}$ Each of the other siblings had four children so there were a total of 19 grandchildren. ${ }^{504}$

Susan and the Otto grandchildren tried to persuade Vieve and the other grandchildren to change the Pokeberry Trust distribution formula so that each grandchild would receive an equal share. ${ }^{505}$ When that effort failed, they devised another plan to increase the number of Otto beneficiaries by having Susan adopt her ex-husband, Jan. ${ }^{506}$ At the time the adoption was formalized in 2003, Jan was 65 years old. ${ }^{507}$ Jan originally agreed not to take anything from the Pokeberry Trust, thereby increasing the respective shares of his children. ${ }^{508}$ However, he later decided to keep his entire share from the Trust. ${ }^{509}$

After Vieve's death in 2005, a controversy arose over whether the May 1972 Trust was intended to be final and legally effective or whether

497 Id. at 313 .

498 Id.

499 See Estate of Pittman v. Tuffree, 163 Cal. Rptr. 527, 531 (Ct. App. 1980); Otto v. Gore, 45 A.3d 120, 137 (Del. 2012); Jenkins v. Jenkins, 14 A. 557, 558 (N.H. 1888).

50045 A.3d 120 (Del. 2012).

501 Id. at 124.

502 Id. The Court of Chancery described the May trust as a "placeholder," and the Supreme Court opinion states that after executing the October trust, "Over the next forty years, the settlors, trustees, and beneficiaries all believed that the October Instrument governed the Pokeberry Trust." Id. at 126-27.

503 Id. at 127.

504 Id. at 128.

505 Id.

$506 I d$.

507 Id. at 129 .

508 Id. at $128-29$.

509 Id. at 129. 
it was merely a preliminary draft. ${ }^{510}$ The Delaware Supreme Court held that only the October 1972 instrument was effective.511 Having concluded that the Pokeberry Trust's assets would be distributed according to the provisions of the October instrument, the court determined that Jan would not be entitled to take a share as a "grandchild" of Bill and Vieve. ${ }^{512}$ The lower court found that Susan adopted her ex-husband "for the sole and improper purpose of thwarting or circumventing the Gores' intentions regarding the Pokeberry Trust."513

On appeal, the Delaware court declared that it was appropriate to consider the purpose of an adoption when deciding whether an adult adoptee was entitled to take a share of the trust property. ${ }^{514}$ Quoting from In re Adoption of Swanson, the court stated that "no court should countenance an adoption to achieve a fraudulent, illegal or patently frivolous purpose." 515 According to the court in Otto, Jan's adoption was made solely to affect the distribution of the Pokeberry Trust in a way that was contrary to the settlors' intent. The court reached this conclusion on the following basis:

Nathan Otto attempted to convince Vieve to amend the Pokeberry formula on her ninetieth birthday, but she rebuffed him. Two weeks later, Jan C. Otto jokingly suggested that Susan adopt him. Within four months, Susan formally adopted Jan C. as her son. The timing of the adoption and the background preceding it, are evidence that the adoption was pursued in order to undermine the Gores' intentions. The fact that Susan kept this adoption secret until Vieve died further evidences that Susan and the Otto Grandchildren knew that they were acting to thwart Vieve's intentions. Finally, Susan testified that the purpose of the adoption was to be "purely a device to even out Pokeberry" a result clearly contrary to the Gores' goal of equalizing expectations. ${ }^{516}$

Accordingly, the court held that Jan was not entitled to take a share of the Pokeberry Trust. ${ }^{517}$

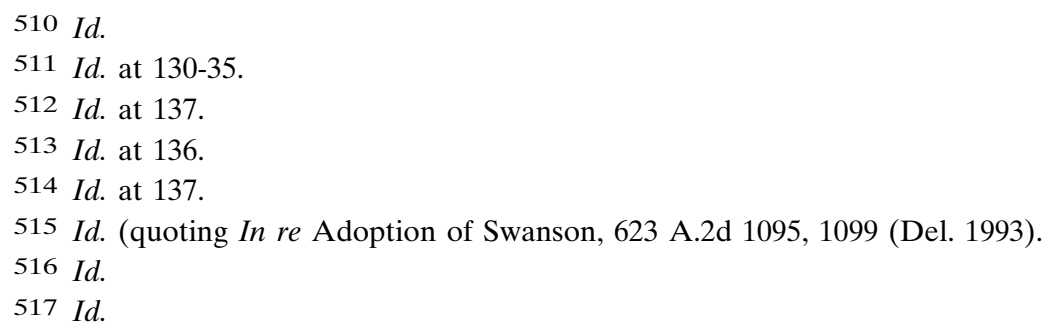




\section{Adult Adoption and Inheritance Rights Reconsidered}

\section{A. Inheritance Rights for Adoptees Under Existing Law}

To summarize, both statutory law and judicial decisions allow minors to inherit from their adoptive parents when they die intestate. In addition, adopted children can generally inherit from other members of their adoptive family by representation. On the other hand, most courts have interpreted their states' adoption statutes to bar minor adoptees from inheriting from their biological parents or from the rest of their biological family. Similar rules govern the right of minor adoptees to partake of class gifts in the wills and trusts established by their adoptive parents or by other members of their adoptive family. At the same time, courts are less willing to allow adopted minors to benefit from class gifts established in the wills and trusts of their biological parents and other biological family members.

However, inheritance rights are quite different where adult adoptees are concerned. Although courts have allowed adult adoptees to inherit from their adoptive parents, they have generally refused to permit adult adoptees to inherit from relatives of their adoptive families. The same is true of class gifts. Instead, the majority approach denies adult adoptees the right to take a share of class gifts provided for in the wills and trusts of other members of their adoptive family, particularly if the adoption occurs after the death of the testator or settlor.

\section{B. Public Policy Issues}

Adoption and inheritance involve a number of public policy issues. These policies are often embedded in state adoption and intestacy statutes. In addition, they are sometimes reflected in common law rules involving wills and trusts.

\section{Adoption Statutes}

An important policy, one that is embodied in numerous statutes and court opinions, is known as the "fresh start" principle. According to this principle, upon adoption, a minor child becomes a full-fledged member of his or her adoptive family and is thereby entitled to the same rights as any of the biological children of the adoptive parents. ${ }^{518}$ In other words, an adopted child not only acquires new parents, but also new siblings, grandparents, aunts, uncles and cousins.519 As a result, adopted children are permitted to inherit through, as well as from, their

518 See In re Newman's Estate, 16 P. 887, 888 (Cal. 1888).

519 See Rein, supra note 31, at 721-22. 
adoptive parents. ${ }^{520}$ This applies to inheritance through intestacy as well as the right to participate in class gifts in wills and trusts.

Another issue, which will be discussed in more detail below, is whether the adoption process is suitable for every type of adult adoption or whether it should be limited to adoptions that more or less replicate a parent-child or family relationship. If so, is it possible to develop a process that fills this gap or should non-family inheritance rights be left to intestacy laws and testamentary provisions?

\section{Intestacy Statutes}

Intestacy statutes historically restricted inheritance to blood relatives of the decedent. ${ }^{521}$ The practice, still found in some states, that "half-bloods" receive a reduced share is a throwback to the traditional emphasis on bloodlines. ${ }^{522}$ Consequently, it is not surprising that judicial interpretations of intestacy statutes in the past reflected the view that decedents would prefer to benefit blood relations rather than unrelated parties. ${ }^{523}$ For this reason, in the past most courts refused to allow adopted children to inherit through their adoptive parents. ${ }^{524}$ However, in more recent times, the "fresh start" rationale of modern adoption laws, along with the weakening concern about family bloodlines, has led most courts to reconsider the status of adopted children and to allow them to inherit as "issue" or "descendants" of their adoptive parents.

In addition, intestacy statutes generally have protected the interests and reasonable expectations of members of the decedent's immediate family. The most obvious example of this concern is the provision for dower or its modern equivalent in common law intestacy statutes which provides financial security to the surviving spouse if the decedent is married. ${ }^{525}$ Statutory provisions for homestead, personal property setasides and family allowances also provide a safety net for the decedent's family. ${ }^{526}$ Furthermore, the decedent's children (or their issue) are almost always the first takers of the decedent's estate.

520 See McClure v. Noble, 602 So. 2d 377, 378 (Ala. 1992); In re Estate of Carlton, 348 So. 2d 896, 896 (Fla. 1977); In re Taylor's Estate, 285 N.W. 538, 541 (Neb. 1939).

521 See Rein, supra note 31, at 721-22.

522 See, e.g., VA. Code AnN. § 64.1-2 (2016).

523 See Conn.Bank \& Tr. Co. v. Bovey, 292 A.2d 899, 902-03 (Conn. 1972); Lutz v. Fortune, 759 N.E.2d 77, 81-83 (Ind. Ct. App. 2001).

524 See Keegan v. Geraghty, 101 Ill. 26, 35-36 (1881); Batcheller-Durkee v. Batcheller, 97 A. 378, 380 (R.I. 1916).

525 Dower rights are not necessary in community property states since community property is divided equally at the death of the first spouse.

526 See Unif. Probate Code $\S \S 2-402$ to 2-404 (Unif. Law Comm’n 2010). 


\section{Wills and Trusts}

There are several policies embodied in the law of wills and trusts that are also relevant to adoption cases. First and foremost is the principle of freedom of disposition. Except in extreme cases, most courts believe that they should carry out the testator's wishes when they are clearly expressed, no matter how unfair or misguided they appear to be.527 In addition, there are a number of doctrines in the law of wills that attempt to carry out a testator's presumed intent by "filling in the gaps" when unforeseen circumstances intervene. For example, antilapse statutes prevent a bequest from lapsing when a beneficiary predeceases the testator. ${ }^{528}$ In addition, children born after the execution of the will are protected by pretermitted child statutes. ${ }^{529}$ Finally, the doctrine of ademption by satisfaction, like the concept of advancements in the case of intestacy, helps to ensure that each member of a beneficiary class will be treated the same. ${ }^{530}$

Courts also purport to respect the settlor's intent when they interpret inter vivos and testamentary trusts. ${ }^{531}$ For example, spendthrift provisions applicable to third-party beneficiaries are still enforced in most states. ${ }^{532}$ In addition, notwithstanding the wishes of the beneficiaries, courts are usually reluctant to modify or terminate testamentary or irrevocable trusts without good reason. ${ }^{533}$ Furthermore, under the influence the Uniform Trust Code, ${ }^{534}$ courts are now increasingly likely to enforce honorary or purpose trusts for pets and other non-charitable purposes. ${ }^{535}$

527 See Shapira v. Union Nat'l Bank, 315 N.E.2d 825 (Ohio Ct. Com. Pl. 1974).

528 See Unif. Probate Code $\$ 2-603$.

529 See id. $\S 2-302$. At the same time, other policies sometimes trump a testator's intent. Thus, for example, virtually all common law states allow a surviving spouse to elect against the will and take a larger share than the decedent's will provides.

530 See Unif. Probate Code § 2-612 (Unif. Law Comm'n 2010).

531 See In re Tr. Created by Belgard, 829 P.2d 457, 459 (Colo. App. 1991); Elliott v. Hittleson, 303 N.W.2d 140, 142 (Iowa 1981); In re Trs. of Harrington, 250 N.W.2d 163, 165 (Minn. 1977).

532 See Richard C. Ausness, The Offshore Asset Protection Trust: A Prudent Financial Planning Device or the Last Refuge of a Scoundrel?, 45 DuQ. L. Rev. 147, 150-52 (2007).

533 See Richard C. Ausness, Sherlock Holmes and the Problem of the Dead Hand: The Modification and Termination of "Irrevocable" Trusts, 28 QuinNiPIAC Prob. L.J. 237, 243-244 (2015).

534 See Unif. Trust Code $\S \S 407-08$ (Unif. Law Comm’n 2013).

535 See Alexander A. Bove, Jr., The Purpose of Purpose Trusts, 18 Real Prop. Tr. \& EsT. L.J. 34 (2004). 


\section{Adult Adoption and Public Policy}

Each of these policies-facilitation of a fresh start for adopted children, deference to the decedent's actual or presumed intent, and protection of the reasonable expectations of the decedent's family-arguably support the right of minor adopted children to inherit from and through their adoptive parents. The fresh start theory mandates equal treatment of adopted children along with other children of the adoptive parents; it is reasonable to assume that other members of the adoptive family would regard adopted children as full-fledged family members; and it is consistent with the policy of recognizing the reasonable expectations of the decedent's family to treat adopted children as heirs and beneficiaries.

However, these policies do not necessarily apply to adult adoptees. Since adult adoptees typically retain strong ties to their biological family and, therefore, are not fully integrated into the family of their adoptive parent, the fresh start theory seems inapplicable to adult adoptees. Because an adult adoptee is not necessarily integrated into the adoptive parent's family, there is no reason to assume that other members of the family would want them to inherit under wills, trusts or intestacy laws. ${ }^{536}$ Nor is it self-evident that adopted adults have a reasonable expectation of inheriting from members of their adoptive family, particularly if they can reasonably expect to inherit from members of their biological family.

There are other reasons to question whether adult adoptees should be able to inherit as a matter of course from members of their adoptive families. In particular, unlike childhood adoptions, which are generally based on altruistic motives, adult adoptions are often motivated by economic or other strategic considerations. ${ }^{537}$ In such cases, where a strong relationship does not exist between the adult adoptee and the adoptive family, a per se rule that allows adoptees to inherit from either their adoptive parents or other members of their adoptive family may not be appropriate ${ }^{538}$ Instead, a more nuanced approach should be considered.

\section{Distinguishing Among Various Types of Adult Adoption}

\section{1. "Familial" Adult Adoptions}

One approach is to condition inheritance rights for adult adoptees on a requirement that the parties to the adoption truly intend to replicate some sort of family relationship. An earlier portion of this Article

536 See In re Estate of Goal, 551 A.2d 309, 312 (Pa. Super. Ct. 1986).

537 See Ratliff, supra note 6, at 1781.

538 See Estate of Pittman v. Tuffree, 163 Cal. Rptr. 527, 531 (Ct. App. 1980); Otto v. Gore, 45 A.3d 120, 137 (Del. 2012); Jenkins v. Jenkins, 14 A. 557, 558 (N.H. 1888). 
described various types of adult adoption scenarios. ${ }^{539}$ For example, some adult adoptions are intended to formalize pre-existing informal parent-child relationships. Other adoptions are based on a preexisting family relationship, as when a close relative adopts the child of another family member. ${ }^{540}$ A third form involves the adoption of a stepchild by the spouse of the adoptee's parent. Although only the first type of adoption is based on the existence of a true parent-child relationship, the other two are based on pre-existing family relationships that replicate the parent-child relationship, at least to some extent. These three categories may be collectively described as "familial" adoptions, since the adult adoptee is not adopted by strangers, but is further integrated into the existing family. Moreover, familial adoptions resemble traditional adoptions in the sense that they are principally motivated by altruistic rather than purely economic objectives.

\section{Adoptions Involving Same-Sex Couples}

Adoptions between same sex couples are also typically motivated, at least to some extent, by altruistic objectives. ${ }^{541}$ However, they are different from familial adoptions because they are primarily viewed as proxies for marriage rather than a means of establishing a parent-child or familial relationship between the parties. Unlike the case with a familial adoption, the adoptee's principal relationship will normally remain with his or her partner and the adoptee's biological family, and not necessarily extend to the partner's family.

\section{Adult Adoptions Based on Affinity}

Another type of adult adoption is based on affinity, that is, an altruistic friendship between two persons that is not obviously sexual in nature. Usually, but not always, one party is the sponsor or mentor of the other. Also, the parties may differ substantially in age, ${ }^{542}$ although in some cases there may be little or no age difference between them. ${ }^{543}$

\section{Adult Adoption for the Purpose of Creating Inheritance Rights}

Finally, an adult adoption may be solely or primarily concerned with creating inheritance rights for one or both of the parties. These

\footnotetext{
539 See Ratliff, supra note 6, at 1781.

540 See, e.g., Collamore v. Learned, 50 N.E. 518 (Mass. 1898); In re Mullaney's Adoption, 25 Pa. C. C. 561 (Ct. Com. Pl. Huntingdon Cty. 1901).

541 See In re Adoption of Swanson, 623 A.2d 1095 (Del. 1993); Ex Parte Libertini, 224 A.2d 433 (Md. 1966).

542 See, e.g., In re Adoption of Sewall, 51 Cal. Rptr. 367, 371 (Dist. Ct. App. 1966).

543 See, e.g., In re Adoption of Elizabeth P.S. by Eileen C., 509 N.Y.S.2d 746 (Fam. Ct. 1986).
} 
types of adoptions include adoptions between spouses, adoptions between unmarried heterosexual couples and some adoptions between unrelated adults. These adoptions have little in common with traditional adoptions because they are not intended to replicate a conventional family structure. Rather, like adoptions in ancient Rome, they are strategic in nature and the essential relationship between the parties is contractual rather than familial in character.

\section{E. Proposed Inheritance Rules}

Keeping in mind the fact that a decedent can provide for an adoptee, whether a minor or an adult, by executing a valid will, I would propose a default rule that would confine inheritance rights to adult adoptees who truly become members of the adoptive parents' family. Other adult adoptees would inherit from members of their adoptive families only if they were expressly provided for in a will or trust. Indeed, it might be better to devise a separate process for these arrangements call them something besides adoption.

\section{1. "Familial" Adult Adoptions}

\section{a. Adoptions Involving a Pre-existing Parent-Child Relationship}

This type of relationship is very close to the typical situation that most adoption statutes contemplate when an adult adopts a minor child. Because there is a pre-existing parent-child or family relationship, it is reasonable to assume that the adoptees will have already been fully integrated into the adoptive family by the time an adoptive parent or relative dies. Arguably, when this type of adoption occurs, the adult adoptee should have all of the rights that a biological child would have, including the right to inherit from and through his or her adoptive parents.

At the same time, unlike with the adoption of a minor, an adult adoptee may also remain in contact with his or her biological family. If that is the case, should an adoptee also retain the right to inherit from or through his or her biological parents? Allowing an adult adoptee to retain the right to inherit from his or her biological parents appears to be inconsistent with the "fair share" policies that are embodied in intestacy statutes as well as the law of wills. Furthermore, the existence of a pre-existing parent-child relationship makes it unlikely that the adoptive child will have maintained close ties with his or her biological family. On balance, therefore, the better default rule might be to bar an adult adoptee from inheriting from members of his or her biological family. 


\section{b. Adoptions Involving a Pre-existing Family Relationship}

A second situation is where a family member wishes to adopt an adult relative. ${ }^{544}$ This arrangement also resembles a conventional adoption in some respects. Although there is no pre-existing parent-child relationship between the parties, there is a pre-existing family relationship so the adoptee is not a complete stranger to the bloodline. This supports the conclusion that an adult adoptee under these circumstances should be able to inherit from and through his or her adoptive parents.

One can also argue that the adoptee should be permitted to inherit from and through his or her biological parents since they are likely to have maintained a close relationship after the adoption. However, in some situations, a dual inheritance problem may arise. This means that person attempts to inherit as both an adoptee and a biological relative of the decedent as when a person adopted by his grandfather seeks to inherit as both the adopted son and the biological grandson of his grandfather. ${ }^{545}$ As in the case of minor adoptees, the better approach is to disallow dual inheritance.

\section{c. Stepchild Adoptions}

Although most stepchild adoptions involve minors, it is possible for a stepparent to adopt an adult stepchild. ${ }^{546}$ Once again, in most cases, the adult adoptee will probably continue to maintain a normal relationship with his or her biological family. Accordingly, as far as inheritance rights are concerned, adult adoptees should be treated the same as adopted minors. In other words, an adult adoptee should be able to inherit from the adoptive parent and his or her spouse. In addition, the adult adoptee should be allowed to inherit from the divorced or deceased biological parent where a prior parent-child relationship existed between them prior to the adoption. ${ }^{547}$

\section{Adoptions between Same Sex Couples}

In the past, same sex couples sometimes used adoption as a marriage substitute. Not only did this form of adoption provide some sort of legal recognition of their relationship, but it offered the prospect of inheritance rights from the other same-sex partner, and possibly from his or her relatives. However, adoption within a same-sex couple in no

544 See Messler, supra note 3, at 1051-52.

545 See, e.g., In re Wilson's Estate, 33 P.2d 969 (Colo. 1934); Wagner v. Varner, 50 Iowa 532 (1879); In re Bartram's Estate, 198 P. 192 (Kan. 1921); Jenkins v. Jenkins, 990 So. 2d 807 (Miss. Ct. App. 2008); In re Benner's Estate, 166 P.2d 257 (Utah 1946).

546 See In re Estate of Brittin, 664 N.E.2d 687 (Ill. App. Ct. 1996).

547 See Unif. Probate Code § 2-119(b) (Unif. Law Comm’n 2010). 
way resembled a conventional adoption since the underlying relationship was a sexual one rather than that of a parent and child. Now that the Supreme Court has upheld the validity of same sex marriages, it is unlikely that same-sex couples will continue to view adoption as an acceptable substitute for marriage. However, if a member of a same sex couple does adopt the other in the future, the adoption should not create inheritance rights to the property of third parties. By the same token, the adoption should not affect existing inheritance rights to the property of members of either party's biological family.

\section{Adoptions Based on Affinity or Economic Advantage Other Than Inheritance}

Unrelated adults sometimes use adoption to publicly declare their friendship and affection for each other, ${ }^{548}$ to prevent a will contest, ${ }^{549}$ or to gain some economic benefit. ${ }^{550}$ In such cases, there is no parent-child relationship or other family connection. Accordingly, it seems that neither party should be allowed to inherit from the other except under the terms of a valid will or trust. However, instead, both parties should retain the right to inherit from and through their respective biological families.

\section{Adoption for the Purpose of Creating or Increasing Inheritance Rights}

Many adult adoptions are made solely for the purpose of creating inheritance rights. While there is nothing wrong with two parties creating inheritance rights between themselves, they can do so by making a will contract and do not need to have one party adopt the other. Using the adoption process to create or increase inheritance rights in the property of third parties is even more problematic and contrary to many of the policies that were discussed above.

548 See In re Adoption of Elizabeth P.S., 509 N.Y.S.2d at 746.

549 See In re Moore's Estate, 47 P.2d 533, 534 (Cal. Dist. Ct. App. 1935); In re Estate of Goulart, 35 Cal. Rptr. 465 (Dist. Ct. App. 1963); Warren v. Prescott, 24 A. 948 (Me. 1892); Hoellinger v. Molzhon, 41 N.W.2d 217 (N.D. 1950).

550 See Coker v. Celebrezze, 241 F. Supp. 783, 787 (E.D. Tenn. 1965) (attempted adoption to qualify for Social Security benefits); In re Adoption of P, 471 A.2d 1220, 1220 (N.J. Super. Ct. Law Div. 1983) (college professor seeking to adopt student in order to qualify him for free tuition); 333 E. 53d St. Assocs. v. Mann, 503 N.Y.S.2d 752, 754 (App. Div. 1986) (one tenant adopting another to benefit from rent control regulations). 


\section{a. Adoptions between Spouses}

Although a few states prohibit the adoption of spouses, ${ }^{551}$ it is apparently possible to adopt a spouse in at least some states. ${ }^{552}$ However, when one spouse adopts another, the resulting relationship does not resemble a traditional adoption. In particular, since the adopted spouse does not become part of the adopting spouse's family (other than being an in-law), there is no reason to grant any inheritance rights as a result of such an adoption. A spouse who desires to make a provision for the other spouse is free to do so by will. Moreover, since the adopted spouse will continue to maintain a relationship with his or her biological family, he or she should also retain whatever inheritance rights that flow from that relationship.

\section{b. Adoptions between Unmarried Heterosexual Couples}

The same analysis applies to unmarried heterosexual couples. Adoptions of this sort are relatively rare and are almost always financially motivated. ${ }^{553}$ As in the case of a same-sex couple, the essence of the relationship is sexual, not parental, and, therefore, adoption is a poor fit for such an arrangement. Consequently, this sort of adoption should not create any inheritance rights to the property of the adoptee's partner or that of any member of the partner's family. However, once again, this arrangement should have no effect on inheritance rights to the property of either party's biological family.

\section{c. Adoptions between Unrelated Parties to Create Inheritance Rights from a Third Party}

A great number of adult adoptions are intended to create or affect the inheritance rights of one or both parties. ${ }^{554}$ Although this practice is not necessarily fraudulent or deceitful, it appears to have little connection with the true purpose of adoption. It certainly does not promote the "fresh start" policy of adoption, nor in most cases is it likely to carry out a third-party decedent's actual or presumed intent. Indeed, this sort of adoption is usually intended to frustrate or distort this intent by adding an unexpected heir or beneficiary to share in the decedent's estate. Not only is this result likely to be contrary to the decedent's intent, but it also interferes with the reasonable expectations of other family members. Consequently, in the absence of an express agreement, the

551 See Unif. Adoption Act $\S 5$-101(a)(1), 9 U.L.A. 109-10 (1994); Mont. Code $\S$ 42-4-402 (1) (2015); Nev. Rev. Stat. § 127.190 (1) (2015); N.C. Gen. Stat. § 48-1-103 (2016).

552 See, e.g., Bedinger v. Graybill's Ex’r, 302 S.W.2d 594 (Ky. 1957).

553 See, e.g., Greene v. Fitzpatrick, 295 S.W. 896, 896 (Ky. 1927).

554 See Ratliff, supra note 6, at 1781. 
parties should not be able to inherit from each other or from other members of the other party's family either by intestacy or as beneficiaries of a class gift.

\section{OTHER ISSUES}

Although this Article is primarily concerned with inheritance rights, there are some ancillary issues that are worth discussing. One issue involves the appropriate formalities for adult adoption. Another issue is what form of notice should be required to any affected third parties. A third issue is what sort of procedure should be required to terminate an adoptive relationship. Finally, there is the question of whether much of the terminology associated with adult adoption should be reexamined.

\section{A. Formalities}

The process of adoption for minors is usually set forth in some detail in each state's adoption statute. Typically, adoption involves a judicial proceeding that is principally concerned with the best interests of the adopted child. This inquiry largely focuses on the fitness of the adoptive parents. The adoptive process is usually much simpler in the case of adult adoption since none of these issues is particularly relevant to the adoption of an adult. Therefore, it makes sense to reduce the adoption process to a bare minimum. A petition, coupled with a short appearance by the parties in the judge's chambers, should be sufficient in most cases. Even that formality might be omitted in the case of an adoption that is solely for the purpose of creating inheritance rights. Since this form of adoption is more analogous to a contract to make a will, perhaps it should not require a formal court proceeding.

\section{B. Notice}

Who, if anyone, should be notified when one adult adopts another? Although a minor adoptee's biological parents must be notified, if possible, and given an opportunity to contest the proposed adoption, that does not seem to serve any useful purpose when an adult is adopted. On the other hand, since "familial" adoptions potentially affect the inheritance rights of the adoptee's biological family, it seems desirable that they be notified in some way. There are various options ranging from transmission of the order of adoption to publication of a "tombstone notice" in a local newspaper.

As far as family members and other interested parties may be concerned, one can assume that the adopting parties will notify them informally. However, in the case of other types of adoption, notice to others may not be necessary if the adoption only affects the inheritance rights 
of the parties themselves. Once again, since this arrangement is like a contract or a will substitute (for which notice to others is not required) rather than an adoption, it is doubtful that notice requirement would serve any useful purpose.

\section{Termination of the Adoptive Relationship}

Traditionally, because adoption was thought to involve the integration of the adoptee into a new family, it was very difficult to rescind or terminate. ${ }^{555}$ Usually family members rather than one of the adoptive parties sought to invalidate the adoption on grounds of fraud, undue influence or failure to follow the prescribed procedures. While there is good reason to maintain this high bar where the adoption of a minor child is involved, it serves no purpose in the case of an adult adoption. Perhaps where a "familial" adoption is concerned, the adoptive relationship should be terminated by a judicial decree with an appearance by one or both parties. However, in other cases, if the rights of third parties are not affected, perhaps either party should have the power to terminate the relationship by written notice to the other.

\section{Terminology}

Many of the terms and concepts used in the adoption process do not accurately describe the relationships involved in an adult adoption. This is particularly true of non-familial adult adoptions. Thus, while it may be appropriate to refer to one party as a "parent" and the other as a "child" in the context of a familial adult adoption, it makes no sense when a member of a same sex couple adopts the other or when two middle-aged adults go through an adoption procedure in order to create inheritance rights. It is purely arbitrary to describe one party as the "parent" and the other as the "child." Likewise, it is inaccurate to describe a relationship between equals as "parental" in nature. Nor is one party really "adopting" the other in the sense of making the adoptee a family member. Instead, perhaps the term "adoption" should be restricted to traditional adoptions and, possibly in the case of adults, to familial adoptions.

One criticism of this approach is that it excludes those who do not qualify for a familial adoption from participating in an adoption process. Should they be allowed to opt for a traditional adoption and refer to each other as parent and child even though these terms are not truly descriptive of their underlying relationship? Although it is a fiction to characterize any type of non-familial relationship as parental in nature, it probably does no harm as long as inheritance rights are not affected.

555 Roman, supra note 91, at 738. 
Therefore, a state should be free to recognize a form of optional "quasi adoption" status for these parties if it wishes to do so.

\section{CONCLUSION}

Many adult adoption statutes contain language, requirements and restrictions that may be relevant to the adoption of minors, though are not appropriate in the context of adult adoptions. This is particularly true when the adoption is not intended to replicate a traditional family structure. In addition, adult adoption statutes seldom set forth the inheritance rights of adoptees. This Article suggests that adult adoption statutes should distinguish between familial adult adoptions and those that are primarily motivated by other objectives. Therefore, it has proposed different rules regarding inheritance rights for each of these types of adoption. 
